\title{
Insufficiently Jurisdictional: The Case Against Treating State Sovereign Immunity as an Article III Doctrine
}

\author{
Katherine Florey $\dagger$
}

TABLE of Contents

1ntroduction

1. The Jurisdictional Characterization of State Sovereign

Immunity Doctrine

A. An Overview of State Sovereign Immunity's

Historical Origins.

B. Three Arguments for the Subject Matter Jurisdiction Theory of Sovereign Immunity

1. The Eleventh Amendment Explanation for Sovereign Immunity's Jurisdictional Status

2. The Article IlI Explanation for Sovereign Immunity's Jurisdictional Status.

3. The "Nature of Sovereign Immunity" Explanation for Sovereign Immunity's Jurisdictional Status

II. Pressures on the Subject Matter Jurisdiction View of

Sovereign Immunity

A. The Move Toward a Balancing Approach in Ex parte

Young Doctrine.

B. The Court's Decreasing Reliance on the

Eleventh Amendment

C. Alternative Characterizations of Sovereign Immunity

Copyright $(02004$ California Law Review, Inc. California Law Review, Inc. (CLR) is a California nonprofit corporation. CLR and the authors are solely responsible for the content of their publications.

$\dagger \quad$ J.D. 2004, School of Law, University of California, Berkeley (Boalt Hall); Law Clerk to Judge William A. Fletcher, Ninth Circuit Court of Appeals. I would like to thank Stephen McG. Bundy, John Hunt, Keenan Kmiec, and the entire Articles Board for their valuable comments and insights. 1 also thank Jesse Ratcliffe and Nikka Rapkin for their thorough and helpful editing. 
III. Consequences of the Subject Matter Jurisdiction View of Sovereign Immunity in Lower Courts...

A. The Jurisdictional Trump: Steel Co. and Issue Ordering........... 1418

B. Absence of Guidance: The Troublesome Sua Sponte Question

C. Oddities and Distractions: The Jurisdictional View as Generator of Judicial Error

1. Schacht v. Wisconsin Department of Corrections 1427

2. Frew v. Hawkins 1428

IV. Possible Alternatives 1431

V. Conclusion 1438 


\title{
Insufficiently Jurisdictional: The Case Against Treating State Sovereign Immunity as an Article III Doctrine
}

\author{
Katherine Florey
}

Even as the Supreme Court has expanded the scope of state sovereign immunity and clarified many of its applications, it has left one fundamental and long-standing puzzle unresolved. The Court has failed to decide whether state sovereign immunity is a question of subject matter jurisdiction-in other words, a specific limitation on the federal judiciary's Article III powers to hear "cases" and "controversies"-or whether it is better conceived as a nonjurisdictional right, defense, or aspect of residual state power. This Comment argues that the Supreme Court's muddled and contradictory pronouncements on the jurisdictional status of sovereign immunity have undermined the doctrine's coherence and perceived legitimacy. This Comment first discusses the doctrinal and practical problems with both the jurisdictional view and the Court's inconsistent adherence to it, and then considers how the Court might formulate a more consistent and coherent view of state sovereign immunity. This Comment concludes that because subject matter jurisdiction is a fundamentally inappropriate way to understand the doctrine of sovereign immunity as the Supreme Court has developed it, the Court should clarify current doctrine by squarely holding that sovereign immunity is not a question of subject matter jurisdiction.

\section{INTRODUCTION}

At least since the Supreme Court's decision in Seminole Tribe $v$. Florida, ${ }^{1}$ it has been a scholarly commonplace to regard the expansion of state sovereign immunity doctrine ${ }^{2}$ as a centerpiece of the Rehnquist

I. 517 U.S. 44 (1996)

2. I have used the term "state sovereign immunity" to refer to the various doctrines that bar suits by individual plaintiffs against states, state agencies, or state officials. Where necessary for clarity, 1 have followed the practice of the Supreme Court in using the term "Eleventh Amendment" as a 
court's New Federalism jurisprudence. The Court's renewed interest in a once-obscure area of law ${ }^{3}$ has caused controversy both in the legal world at large, where commentators have referred to the post-Seminole line of cases as everything from a "landmark" to an example of "judicially sanctioned state lawlessness," and in the Court itself: the current justices, in a long line of 5-4 opinions, have debated the historical origins of current sovereign immunity doctrine with, in the words of Justice Scalia, "a degree of repetitive detail that has despoiled our northern woods."

As it has expanded the scope of state sovereign immunity, the Court-frequently over vigorous dissents, but sometimes in brief, unanimous opinions-has also clarified many unsettled aspects of the doctrine. lt has held, for example, that a state's decision to remove a case to federal court extinguishes its ability to subsequently invoke Eleventh Amendment protections, ${ }^{7}$ that the presence of a sovereign immunity-barred claim does not destroy federal jurisdiction over a case in which other federal issues remain, ${ }^{8}$ and that sovereign immunity extends to proceedings against a state before federal administrative agencies. ${ }^{9}$ In the process, the Court has speedily developed a substantial and wide-ranging body of sovereign immunity doctrine.

Notably, however, even as the Court has expanded the scope of state sovereign immunity and clarified many of its applications, it has left one fundamental and long-standing puzzle unresolved. It has never really determined what sovereign immunity is. ${ }^{10}$ That is, the Court has failed to decide whether state sovereign immunity is a question of subject matter jurisdiction--in other words, a specific limitation on the federal judiciary's Article III powers to hear "cases" and "controversies"11_-or something else

shorthand for state sovereign immunity doctrine, even though under some theories-and according to the argument of this Comment-the concepts are analytically distinct.

3. See William A. Fletcher, The Eleventh Amendment: Unfinished Business, 75 NOTRE DAME L. REv. 843 (2000) [hereinafter Unfinished Business] (noting that at the time of his 1975 graduation from law school he had never studied the Eleventh Amendment).

4. J. Harvie Wilkinson, Is There a Distinctive Conservative Jurisprudence?, $73 \mathrm{U} . \mathrm{CoLO} . \mathrm{L}$. REV. 1383, 1391 (2002).

5. Chrystal Bobbitt, Domestic Sovereign Immunity: A Long Way Back to the Eleventh Amendment, 22 WhITTIER L. REv. 531 (2000). (1999).

6. College Sav. Bank v. Fla. Prepaid Postsecondary Educ. Expense Bd., 527 U.S. 666, 688

7. Lapides v. Bd. of Regents, 535 U.S. 613 (2002).

8. Wis. Dept. of Corr. v. Schacht, 524 U.S. 381, 391 (1998).

9. Fed. Mar. Comm'n v. S.C. State Ports Auth., 535 U.S. 743 (2002).

10. See George D. Brown, State Sovereignty Under the Burger Court-How the Eleventh Amendment Survived the Death of the Tenth, 74 GEo. L.J. 363, 367 (1985) (noting that "there is considerable disagreement over whether [E]leventh [A]mendment doctrine can be fitted under a general label such as jurisdiction, sovereign immunity, or state sovereignty. The Court has used these terms, sometimes interchangeably, and all three can be found in the same opinion.").

11. Schacht, 524 U.S. at 391 (reserving the question and noting that the court has never decided it). 
entirely: an absence of personal jurisdiction, ${ }^{12}$ a right, ${ }^{13}$ an affirmative defense, ${ }^{14}$ an absolute immunity, ${ }^{15}$ a power reserved to the states under the Tenth Amendment, ${ }^{16}$ a common law doctrine, ${ }^{17}$ or simply a state of constitutional being that exists by default because the federal government does not possess the power to alter it. ${ }^{18}$ Moreover, in recent years, even as the Court has continued from time to time to describe sovereign immunity as an Article III doctrine, ${ }^{19}$ such competing characterizations have proliferated.

Whether sovereign immunity is a limitation on Article III subject matter jurisdiction ${ }^{20}$ is a question of long standing. As the contours of current sovereign immunity doctrine have taken shape, courts have frequently noted the ways in which it is both like and unlike such fundamental Article III requirements as justiciability. There is much to be said for both jurisdictional and nonjurisdictional views. On the one hand, the Eleventh Amendment, long the textual anchor for the Supreme Court's sovereign immunity decisions, parallels the language of Article III, suggesting an intent to directly amend it. ${ }^{21}$ In keeping with this theory of the amendment's meaning, the Court has frequently referred to sovereign immunity as a "jurisdictional bar" and a limit on its Article III powers. ${ }^{22}$ Moreover, some aspects of sovereign immunity doctrine are consistent with the way in which questions of subject matter jurisdiction are treated. For example, both may be raised for the first time on appeal; similarly, both may be raised by the court sua sponte. ${ }^{23}$

However, sovereign immunity doctrine contains elements that are inconsistent with regarding it as a limit on subject matter jurisdiction. While parties cannot ordinarily create a basis for federal jurisdiction by

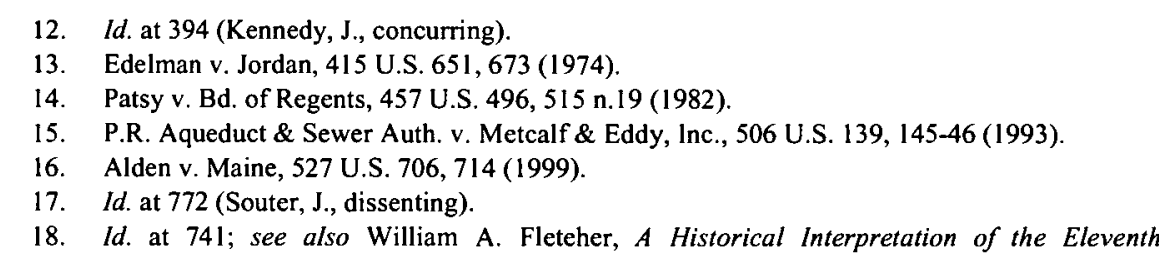
Amendment, 35 STAN. L. REv. 1033, 1087-1131 (1983) [hereinafter Historical Interpretation] (arguing that the bounds of a sovereign immunity doctrine should be seen as a question of federal power generally, not federal judicial power in particular); Caleb Nelson, Sovereign Immunity as a Doctrine of Personal Jurisdiction, 115 HaRv. L. Rev. 1559, 1626 (2002) (viewing Congress's power to subject states to suit as the key constitutional question arising from the doctrine of state sovereign immunity).

19. See, e.g., Seminole Tribe v. Florida, 517 U.S. 44, 72 (1996).

20. Because the type of "jurisdiction" this Comment discusses is subject matter jurisdietion under Article 111, for the sake of convenience, I will refer to "Article III" and "jurisdietional" doctrines interchangeably.

21. See Brown, supra note 10, at 367 (finding "considerable justification" in the text for treating sovereign immunity as "just another subject of the eomplicated rules governing federal jurisdiction generally").

22. Edelman v. Jordan, 415 U.S. 651, 678 (1974).

23. See ERWIN Chemerinsky, Federal JuRISDiction $§ 7.3$, at 398-99 (1999). 
consenting to litigate in federal court, a state may waive sovereign immunity both explicitly and by its conduct during litigation. ${ }^{24} \mathrm{~A}$ court may raise an Eleventh Amendment issue sua sponte; by contrast, it must address Article III matters, such as standing or an absence of federal question jurisdiction, as soon as they come to its attention. ${ }^{25}$ Congress may, when acting pursuant to its Fourteenth Amendment authority, abrogate state sovereign immunity; ${ }^{26}$ it has no corresponding power with respect to any other Article III doctrine. ${ }^{27}$ Finally, state sovereign immunity, unIike any other Article III question, is subject to a broad and important exception: under the doctrine of Ex parte Young, a suit for prospective injunctive relief against a state official is not considered a suit against the state and may be pursued in federal court. ${ }^{28}$

While courts have Iong acknowledged this particular set of similarities and differences between sovereign immunity and subject matter jurisdiction, the degree to which the doctrines are alike is in other respects unresolved. When the Court in Steel Co. v. Citizens for a Better Environment held that questions of standing, as threshold jurisdictional issues, must always be considered first, even if a case can be more easily decided on the merits, ${ }^{29}$ it did not specify whether the same principle applies to Eleventh Amendment issues. As a result, the lower courts are divided on the question. As one court has put it, if sovereign immunity is somewhat jurisdictional but apparently less jurisdictional than Article III doctrines, is it "sufficiently jurisdictional" to bar a court from considering the merits

24. See Lapides v. Bd. of Regents of Univ. Sys. of Ga., 535 U.S. 613 (2002).

25. See Calderon v. Ashmus, 523 U.S. 740 (1998).

26. See, e.g., Nev, Dep't of Human Res. v. Hibbs, 538 U.S. 721, (2003) (noting that Congress may abrogate state sovereign immunity if it makes its intention to do so "unmistakenly clear in the language of the statute and acts pursuant to a valid exercise of its power under $\S 5$ of the Fourteenth Amendment"). Although Congress's ability to abrogate state sovereign immunity pursuant to its Fourteenth Amendment Enforcement Clause powers is an important aspect of the doctrine, it is somewhat beyond the scope of this Comment, since it raises questions about the scope of Congress's Article 1 powers as well as the limits of the federal judiciary's Article 111 powers.

27. By contrast, for example, the Supreme Court has suggested that Congress cannot circumvent justiciability requirements by broadly granting standing to potential plaintiffs. See Lujan v. Defenders of Wildlife, 505 U.S. 155 (1992); CHEMERINSKY, supra note 23, at 70.

28. See Chemerinsky, supra note $23, \S 7.5$, at 411 . These four exceptions do not exhaust the circumstances under which a state may, notwithstanding sovereign immunity, be named as a defendant. For example, the United States may sue a state consistent with the Eleventh Amendment; the Supreme Court has also held that one state may allow private individuals to sue another state in its courts. See Nevada v. Hall, 440 U.S. 410 (1979); United States v. Mississippi, 380 U.S. 128 (1965). Finally, in Franchise Tax Board v. Hyatt, 538 U.S. 488 (2003), the Court recently appeared to reaffirm what is, in light of Alden $v$. Maine's extension of sovereign immunity protections to state courts, a somewhat puzzling exception. Hyat $t$ held that Nevada was not required to give full faith and credit to California statutes extending greater sovereign immunity protections under California law than Nevada would have given to its own agencies.

29. 523 U.S. $83(1998)$. 
first $?^{30}$ The circuits have also reached different conclusions on other sovereign immunity questions that involve jurisdictional issues, such as the wisdom and necessity of raising sovereign immunity sua sponte ${ }^{31}$ and whether the Eleventh Amendment poses a jurisdictional bar to a court's power to enforce an otherwise-valid consent decree against a state. ${ }^{32}$

As long as the Supreme Court fails to state clearly whether sovereign immunity is or is not jurisdictional, lower courts will remain in confusion and disagreement as to how to treat these and similar concerns. Because Article III limits are fundamental to the federal courts' role in the constitutional scheme-and have become even more so under the federalismminded Rehnquist court ${ }^{33}$ - lower courts have felt compelled to consider the restraints sovereign immunity might impose on the scope of federal judicial power. ${ }^{34}$ Compounding the problem, lower courts have been confronted with sovereign immunity questions with increasing frequency, as the states have acted to take advantage of sovereign immunity's expanding scope. $^{35}$

The unresolved jurisdictional status of sovereign immunity affects the ordinary course of litigation in ways both trivial and serious. To begin with, it creates a host of practical inconsistencies. A novice attorney at a state agency, for example, who wanted to assert a claim of sovereign immunity in a pending suit, might find herself legitimately perplexed as to how to proceed. Different courts have variously required sovereign immunity claims to be brought as a I2(b)(1) motion ${ }^{36}$ (to dismiss for lack of subject matter jurisdiction), a $12(\mathrm{~b})(6)$ motion $^{37}$ (failure to state a claim on which relief can be granted), or even a $12(\mathrm{~b})(2)$ motion $^{38}$ (lack of personal

30. See United States ex rel. Long v. SCS Bus. \& Technical Inst., I73 F.3d 890, 893 (D.C. Cir. 1999).

31. See, e.g., Higgins v. Mississippi, 217 F. 3d 95I, 953 (7th Cir. 2000).

32. See Jeremy Wright, Federal Authority to Enforce Consent Decrees Against State Officials, 6 TEX. F. ON C.L. \& C.R. 401 (2002).

33. See, e.g., Steel Co. v. Citizens for a Better Environment, 523 U.S. 83, 101 (1998) (finding that " $[t]$ he statutory and (especially) constitutional elements of jurisdiction are an essential ingredient of separation and equilibration of powers," requiring federal courts to address Article III standing issues before considering the merits); Lujan v. Defenders of Wildlife, 504 U.S. 555, 576 (1993) (holding that Congress cannot by statute "convert the undifferentiated publie interest in executive officers' compliance with the law" into a concrete individual right giving rise to Article 111 standing).

34. See, e.g., Parella v. Ret. Bd. of R.I. Employees' Ret. Sys., 173 F.3d 46, 53 (Ist Cir. I999) (considering the implications of the Supreme Court's decision in Steel Co. for the question of whether sovereign immunity is jurisdictional).

35. See, e.g., Kenneth N. Klee, James O. Johnston, \& Eric Winston, State Defiance of Bankruptcy Law, 52 VAND. L. REv. 1527, 1530-32 (1999) (describing the increasingly common state practice in the wake of Seminole Tribe of violating bankruptcy laws, then using assertions of sovereign immunity to avoid enforcement).

36. See Union Pac. R.R. Co. v. Burton, 949 F. Supp. 1546, 1550 (D. Wyo. 1996) (reviewing conflicting practices in various courts before concluding that the motion is one of subject matter jurisdiction).

37. See id.; Baxter by Baxter v. Vigo County Sch. Corp., 26 F.3d 728, 730 (7th Cir. 1994).

38. See In re PEAKSolutions Corp., 168 B.R. 918, 922 (Bankr. D. Minn. 1994). 
jurisdiction). Litigants may face more serious uncertainties as well. For example, a plaintiff who has won and had upheld upon appeal a successful civil rights suit against a state official may be distressed to learn that the defendant may be allowed to assert a sovereign immunity defense as late as a Supreme Court brief. ${ }^{39}$

While the Supreme Court's recent sovereign immunity jurisprudence has been subject to abundant criticism, the aim of this Comment is not to re-fight the still-ongoing battles over the desirability and historical legitimacy of viewing the Eleventh Amendment expansively. Rather, it is to argue that subject matter jurisdiction is a fundamentally inappropriate way to understand the doctrine of sovereign immunity as the Supreme Court has developed it. As a result, the Supreme Court's muddled and contradictory pronouncements on the jurisdictional status of sovereign immunity have undermined the doctrine's coherence and perceived legitimacy. This Comment thus takes the position that the Supreme Court should clarify the current doctrine by squarely holding that sovereign immunity (except perhaps in certain limited circumstances ${ }^{40}$ ) is not a question of subject matter jurisdiction.

For the Court to adopt a consistently nonjurisdictional view would be an improvement over the current irresolution for two reasons. First, it would bring greater clarity to an area of doctrine too important to leave unsettled. Second, it is simply a better way of understanding the Supreme Court's state sovereign immunity jurisprudence as it has evolved-better in the sense of creating fewer doctrinal conundrums and fewer needless hurdles for courts and litigants that lack textual or doctrinal justification. It is because of this second set of concerns that the Court, in setting forth an alternative characterization of sovereign immunity, should take care to choose a position that is itself consistent with the Court's past practice. Nonjurisdictional characterizations of sovereign immunity abound in the Supreme Court's past opinions, but some of these (such as the idea that sovereign immunity functions as a constitutional right) have the potential to create as much confusion as the jurisdictional view. Therefore, it is not

39. See Ford Motor Co. v. Dep't of Treasury, 323 U.S. 459, 467 (1945) (allowing sovereign immunity to be raised for the first time before the Supreme Court). But see Hill v. Blind Indus. \& Servs. of Maryland, 179 F.3d 754, 760 (9th Cir. 1999) (suggesting that more recent Supreme Court cases have undercut Ford's holding).

40. An exception might be made for suits against states by citizens of other states, which the Eleventh Amendment explicitly bars and which might logieally be regarded as jurisdictionally precluded. See Nelson, supra note 18, at 1626 (arguing that suits against states by foreign-state citizens should be considered outside the scope of federal courts' subjeet matter jurisdietion, despite the fact that the Supreme Court has not regarded such suits as distinct from other suits against states). The scope of this prohibition - that is, whether it would bar such suits only in diversity or also when the basis for the Article 111 court's jurisdiction is the presence of a federal question-would depend on the Court's interpretation of the Eleventh Amendment. See Historical Interpretation, supra note 18, at 1033-34. 
merely important that the Court clarify sovereign immunity's jurisdictional status; it is also important how it does so.

This Comment approaches this problem by first discussing the doctrinal and practical problems with both the jurisdictional view and the Court's inconsistent adherence to it, and then considering how the Court might formulate a more consistent and coherent view of state sovereign immunity. Part I outlines the basic doctrinal foundation of state sovereign immunity and its early historical development. It reviews the main arguments for considering state sovereign immunity a limit on subject matter jurisdiction: first, that the Eleventh Amendment has the effect of removing suits against state defendants from the federal courts' Article III powers; second, that the doctrine, like questions of standing, is a limit inherent in Article III's use of the terms "judicial power" or "cases and controversies"; finally, that state sovereign immunity and subject mattcr jurisdiction operate in ways that are similar in practice. Part I then goes on to reject these arguments, both because they fail to adequately explain the contours of modern sovereign immunity doctrine and because the Court has never fully embraced them.

Part II argues that developments in sovereign immunity doctrine over the past few decades have rendered the jurisdictional view increasingly untenable. First, it argues that the Supreme Court's reliance on a progressively more pragmatic approach to the Ex parte Young exception to state sovereign immunity is inconsistent with the formalism a jurisdictional view requires. It then examines the Court's recent suggestions that the doctrine arises not from the Eleventh Amendment text but from the inherent nature of state sovereignty itself - a development that renders the jurisdictional view increasingly implausible. In conclusion, Part II makes the case that, as the doctrine's scope has expanded, the Court has presented nonjurisdictional views of sovereign immunity with increasing frequency.

Part III examines how the Court's inconsistent suggestions that sovereign immunity is jurisdictional have created problems for lower courts. Specifically, it argues that state sovereign immunity's unresolved status has hindered the ability of lower courts to grapple with the doctrine in three ways: by imposing constraints on judicial management of sovereign immunity issues, by providing inadequate guidance in situations where they are called upon to exercise discretion, and by perpetuating misunderstandings that have led them down erroneous doctrinal paths.

Finally, Part IV considers alternatives to state sovereign immunity's current unsettled status, starting with characterizations the Supreme Court itself has considered. It argues that, of the possible models the Court has advanced, treating the doctrine as an immunity or defense is the view that best comports with the Court's current practice. The Comment concludes by arguing that, because a majority of justices appears willing to reexamine 
state sovereign immunity's jurisdictional status, the Court should explicitly disclaim the jurisdictional notion in favor of the defense or immunity characterization of sovereign immunity.

I.

\section{The Jurisdictional Characterization of State Sovereign IMMUNITY DOCTRINE}

That federal courts possess only limited subject matter jurisdiction is "a principle of first importance" in the constitutional scheme. ${ }^{41}$ In order for a federal court to hear the merits of a particular case, the court must possess statutory authority to do so, and such authority must not exceed the limits on the judicial power established by Article III of the Constitution. ${ }^{42}$

Because Article III jurisdictional limits protect both the separation of powers and the balance between the federal government and states, courts treat these limits in a way that gives priority to those interests, even when this approach fails to "[comport] with notions of system economy or efficiency." ${ }^{43}$ The party seeking to invoke a federal court's jurisdiction bears the burden of proving that jurisdiction is proper. ${ }^{44}$ The court also has an independent responsibility to inquire into its own jurisdiction; a case may - indeed, must - be dismissed at any point if the court determines it lacks jurisdiction over the case, even if all issues have been fully litigated on the merits. ${ }^{45}$ Moreover, the parties cannot confer jurisdiction on the court by waiver, consent, or estoppel. ${ }^{46}$

The Supreme Court has never consistently held that any of these procedural constraints applies to state sovereign immunity cases. Most circuits allot the burden of proof to the state asserting sovereign immunity, ${ }^{47}$ and the Supreme Court has recently held that federal courts need not raise sovereign immunity issues sua sponte. ${ }^{48}$ Additionally, states have virtually unlimited scope to waive sovereign immunity ${ }^{49}$-an ability of which they

41. Charles alan Wright et al., 13 federal Practice \& Procedure 2d $\$ 3522$ (1984, updated 2003).

42. Id. Familiar Article III requirements include the requirement that the case be justiciable-that is, that it concern a genuine "casc or controversy" between parties-and that it fall within one of the nine categories of cases the Constitution grants the federal courts authority to hear.

43. Id.

44. Id.

45. Id.

46. Id.

47. See, e.g., Gragg v. Ky. Cabinet for Workforce Dev., 289 F.3d 958 (6th Cir. 2002); Christy v. Pa. Turnpike Comm'n, 54 F.3d 1I 40, 1144 (3rd Cir. 1995); Baxter by Baxter v. Vigo County Sch. Corp., 26 F.3d 728, 735 (7th Cir. 1994).

48. See Wis. Dept. of Corr. v. Schacht, 524 U.S. 381,389 (1998).

49. See Christina Bohannan, Beyond Abrogation of Sovereign Immunity: State Waivers, Private Contracts, and Federal Incentives, 77 N.Y.U. L. REv. 288 (noting that the Supreme Court "repeatedly has confirmed that sovereign immunity from suit in federal court is a privilege that the state may waive at its pleasure"). 
frequently take advantage in order to maintain credibility in the marketplace $^{50}$ and to contest lawsuits they deem easily winnable. ${ }^{51}$

However, despite sovereign immunity's failure to conform to the Article III jurisdictional model, the Court has frequently stated that the doctrine, whether or not rooted in the Eleventh Amendment, is either a limit on subject matter jurisdiction or something closely analogous to it. In Pennhurst State School \& Hospital v. Halderman, for example, the Court made what remains perhaps its most sweeping pronouncement on the subject, describing sovereign immunity as "a constitutional limitation on the federal judicial power established in Art[icle] III" that effectively "deprives federal courts of any jurisdiction to entertain such claims. $" 52$

Even where the Court has declined to characterize state sovereign immunity in such stark jurisdictional terms, it has often suggested that sovereign immunity doctrine is rooted in Article $\mathrm{III}$ and functions in a manner similar to subject matter jurisdiction. Thus, the court has found that state sovereign immunity "restricts the judicial power under Article III," 33 "partakes of the nature of a jurisdictional bar," 54 and "sets forth an explicit limitation on federal judicial power of . . compelling force." ss

The Court has thus occupied an awkward position, frequently describing sovereign immunity as jurisdictional yet imposing none of the procedural consequences that would seem to follow from that characterization. This Part explores the textual and historical basis for this conundrum. It begins by briefly sketching the doctrine's history, and then goes on to discuss the principal arguments that the Court and commentators have made in support of the Article III interpretation of state sovereign immunity. Concluding that the jurisdictional view is not mandated by either the Eleventh Amendment or Article III, this Part argues that it is also an inaccurate and misleading way to understand state sovereign immunity jurisprudence as it has evolved.

\section{A. An Overview of State Sovereign Immunity's Historical Origins}

Historically, the doctrine of sovereign immunity derives from the traditional prohibition on suits against the British crown. ${ }^{56}$ While the American colonies appear to have differed in the extent to which they

50. A large number of states, for example, waive sovereign immunity in contract actions with private parties. See Renna Rhodes, Principles of Governmental Immunity in Texas, 27 ST. MARY's L.J. $679,706 \mathrm{n} .138$ (listing twenty-three state statutes waiving immunity).

51. See John T. Noonan, Jr., Narrowing the Nation's Power: The Supreme Court Sides WITH THE STATES 58-60 (2002).

52. 465 U.S. $89,98-99$ \& n.8 (1984).

53. Seminole Tribe v. Florida, 517 U.S. 44, 72 (1996).

54. Edelman v. Jordan, 415 U.S. 651,678 (1974).

55. ld.

56. See William Blackstone, Commentaries *244. 
incorporated the doctrine, ${ }^{57}$ the issue, after 1787 , was of enough concern to the newly independent nation that it was extensively discussed in the debates over constitutional ratification. Specifically, many participants in state ratifying conventions raised concerns that Article III, with its language extending the federal judicial power to suits "between a State and Citizens of another State" and "between a State... and foreign...Citizens," 58 would permit states to be "dragged into court" against their will. ${ }^{59}$ While some supporters of the Constitution found this prospect acceptable and even, in a democracy, desirable, other participants were disturbed by the prospect and required assurances that the language of the new Constitution did not mandate such a result. ${ }^{60}$

Many unresolved and acutely controversial questions about the historical basis for sovereign immunity doctrine remain, including the degree to which the doctrine was actually honored in the legal systems of the individual colonies and the effect that citizens and ratifiers believed the new Constitution would have on existing sovereign immunity practice. ${ }^{61}$ However, popular sentiment in favor of at least some form of sovereign immunity appears to have coalesced by the Supreme Court's 1793 decision in Chisholm v. Georgia. In Chisholm, the Court appeared to reject the existence of a constitutional principle of sovereign immunity, holding-by a four-to-one decision in which each judge wrote separately-that Georgia could be made a defendant in a suit by a South Carolina citizen. The majority opinions relied largely on the text of Article III, concluding that its language extending the judicial power to "Controversies ... between a State and Citizens of another State"62 unambiguously permitted such suits. ${ }^{63}$ Some of the opinions also drew on historical understanding and practice in finding the action allowable. ${ }^{64}$ The sole dissenter, Justice Iredell, relied principally on statutory rather than constitutional grounds. ${ }^{65}$

57. See, e.g., John J. Gibbons, The Eleventh Amendment and State Sovereign Immunity: A Reinterpretation, 83 CoLuM. L. REv. 1889, $1895-99$ (1983) (surveying colonial statutes and court decisions that permitted some civil remedy against the government).

58. U.S. ConsT. art. 111, § 2.

59. John Marshall, quoted in 3 Debates on the Federal Constitution 555 (J. Elliot $2 \mathrm{~d}$ ed.

1863).

60. See generally CHEMERINSKY, supra note 23, at 390-96.

61. Id.

62. U.S. Const, art. Ill, § 2, cl. 1.

63. See, e.g., Chisholm v. Georgia, 2 U.S. (2 Dall.) 419, 450 (Blair, J.) ("The Constitution of the United States is the only fountain from which 1 shall draw... [T] je judicial authority of the United States . . . is expressly extended . . to controversies between a state and citizens of another state.").

64. See, e.g., id. at 461 (Wilson, J.) (surveying practices of various sovereign governments to conclude that "conceming the laws and practice of other States and Kingdoms [there is] nothing against, but much in favor of, the jurisdiction of this Court over the State of Georgia.").

65. Justice lredell argued that the Judiciary Act of 1789 did not provide for actions in assumpsit against states, and since such actions were unknown at common law, the Constitution did not confer on the judiciary power to hear them absent specific authorization by Congress. See id. at 449-50. Justice Iredell's dissent left unresolved the question of whether Congress in fact possessed the power to 
The result in Chisholm provoked widespread outrage. ${ }^{66}$ An amendment overturning its result was passed by Congress in less than three weeks and was ratified by $1795 .{ }^{67}$ What became the Eleventh Amendment to the Constitution reads: "The Judicial power of the United States shall not be construed to extend to any suit in law or equity, commenced or prosecuted against one of the United States by Citizens of another State, or by Citizens or Subjects of any Foreign State." ${ }^{168}$ Although the meaning of this language does not appear ambiguous on its face, it has nevertheless caused controversy. The wording of the Eleventh Amendment has appeared to many commentators ${ }^{69}$ to directly reference the portion of Article III providing for federal diversity jurisdiction in suits by a citizen of one state against another state and stating that "the Judicial power shall extend" to various enumerated categories of "Cases" and "Controversies." " In fact, some scholars have argued that the Eleventh Amendment simply removed alien-state diversity as an independent basis for federal jurisdiction, while continuing to permit the exercise of federal question jurisdiction against state defendants. ${ }^{71}$ Providing some support for this interpretation is the fact that Congress rejected a more expansive earlier draft (interestingly, not cast in terms of jurisdiction) that would have provided "[t]hat no state shall be liable to be made a party defendant in any of the judicial courts... established under the authority of the United States, at the suit of any person or persons." 72

The Supreme Court had little occasion to consider the effective scope of the Eleventh Amendment until the late nineteenth century. Before Congress granted the federal courts federal question jurisdiction in $1875,{ }^{73}$ state sovereign immunity issues in practice arose only rarely. ${ }^{74}$ The few cases in which the issue did arise suggest that the Court tended to interpret both the Eleventh Amendment and any common law doctrine of state

authorize such a suit under the Constitution, with Iredell suggesting in dicta that he believed it did not. Id.

66. See Historical Interpretation, supra note 18, at 1058 (describing the "immediate and hostile" public reaction)

67. John V. Orth, The Judicial Power of the United States: The Eleventh Amendment IN AMERICAN History 20-2 I (1987).

68. U.S. CONST. amend. XI.

69. See Brown, supra note 10, at 367; Carlos Manuel Vazquez, What Is Eleventh Amendment Immunity?, 106 YALE L.J. 1683, 1700 (1997) (noting that the Eleventh Amendment's phrasing "suggests that it relates only to federal jurisdiction," although ultimately finding that this reading leads to a falsely dichotomous view of the amendment's meaning).

70. U.S. CoNST. art III, § 2; Historical Interpretation, supra note 18.

7I. See, e.g., Unfinished Business, supra note 3, at 848. Judge Fletcher has acknowledged that the diversity theory of the Eleventh Amendment, whatever its historical merit, has "ceased to matter," since with its decision in Alden v. Maine the Court "cut the last tie between its Eleventh Amendment case law and the text of the Amendment." $I d$. at 857 . This idea is further explored in Part IIB infra.

72. Historical Interpretation, supra note I8, at 1058 (discussing the amendment's drafting).

73. Act of Mar. 3 I875, ch. I37, (18 Stat.) 470.

74. See Gibbons, supra note 57, at 1941. 
sovereign immunity narrowly. ${ }^{75}$ In the 1870 s, however, the Court began slowly to revise its understanding of state sovereign immunity. One commentator has suggested that the Court's change of heart was a direct response to the financial woes of Southern states, whose inability to honor Reconstruction-era bonds had created a political crisis. ${ }^{76}$ In any event, the Court, in a series of cases involving such defaults, found for the states and against the bondholders, on grounds that suggested that state sovereign immunity was a far more extensive doctrine than previous cases had acknowledged. ${ }^{77}$

The Court's shift in direction culminated with the 1890 case of Hans v. Louisiana. ${ }^{78}$ In Hans, a case concerning Louisiana's efforts to legislatively repudiate its bond obligations, the Court explicitly took up the question of the Eleventh Amendment's reach. It found that, although the plaintiff's Impairment of Contracts Clause claim against Louisiana provided an otherwise adequate basis for federal jurisdiction, the suit was nevertheless barred by the doctrine of sovereign immunity. Rejecting what it described as the "anomalous" and "startling" proposition that the significance of the Eleventh Amendment was confined to its literal terms, the Court held that it would be an "absurdity" to subject unconsenting states to suits by private citizens simply because they happened to reside instate. $^{82}$

As the following section will discuss, the Hans Court did not explicitly address the jurisdictional issue. Perhaps because the case was a departure from precedent- - or, at least, a significant extension of $i^{83}$ - the Court employed somewhat inscrutable reasoning that has been subject to multiple interpretations. Hans has been invoked by subsequent justices as support for everything from a strict jurisdictional view of sovereign immunity ${ }^{84}$ to a

75. See id. at 1968-71.

76. See id. at 1977-98. Several changes in the Court's membership between 1875 and the Hans decision in 1890 may also have affected this doctrinal shift. See id. at 1985 (addition of Justice Woods), 1998 (Justices Brewer and Fuller).

77. See id. at 2000-02; see also Antoni v. Greenhow, 107 U.S. 769 (1882); Louisiana v. Jumel, 107 U.S. $711(1882)$.

78. 134 U.S. 1 (1890). The four justices who typically dissent in sovereign immunity cases also see Hans as a break with earlier practice. See Seminole Tribe v. Florida, 517 U.S. 44, 100 (1996) (Souter, J., dissenting) (" [W]e have two Eleventh Amendments, the one ratified in 1795, the other (socalled) invented by the Court nearly a century later in Hans $v$. Louisiana.").

79. Hans, 134 U.S. at 10-11.

80. Id. at 12 .

81. Hans did clearly acknowledge that "[u]ndoubtedly, a state may be sued by its own consent." Id. at 17 .

82. Id. at 15

83. See Gibbons, supra note 57, at 2000 (discussing Hans's rewriting of Eleventh Amendment history).

84. See Seminole Tribe v. Florida, 517 U.S. 44, 45 (1996) (stating that the Eleventh Amendment "restricts the judicial power under Article III" and that any other understanding of the Amendment would "eviscerate[] the Court's decision in Hans). 
contention that sovereign immunity is a common-law background principle subject to unlimited modification by Congress. ${ }^{85}$ As a result, Hans is hardly the last word on the jurisdictional issue, and the Court has in some respects moved well beyond it. Cases such as Alden v. Maine, ${ }^{86}$ for example, in which the Court held that sovereign immunity barred suits against unconsenting states in state court as well as federal court, have expanded the doctrine beyond the federal question jurisdiction context of Hans. Yet Hans, which was explicitly reaffirmed by the Supreme Court's 1996 opinion in Seminole Tribe ${ }^{87}$ still forms the foundation of the Court's sovereign immunity doctrine. The following section, in examining the main arguments that the Supreme Court and commentators have relied upon in support of a jurisdictional view of sovereign immunity, thus focuses on the reasoning in Hans and the subsequent cases that have built on it.

\section{B. Three Arguments for the Subject Matter Jurisdiction Theory of Sovereign Immunity}

Using Hans as a starting point, this section considers three possible arguments for viewing state sovereign immunity as a limit on Article III subject matter jurisdiction. First, it considers the position that the Eleventh Amendment transformed Article III by introducing a principle of sovereign immunity into the Constitution, thus barring suits by individual citizens against states. This section then discusses a second, more recently developed theory that the judicial power granted in the original Constitution did not encompass the ability to hear suits against state defendants. Finally, this section briefly considers a third, nontextual argument founded on the functional similarities between state sovereign immunity and jurisdictional restrictions. Ultimately, this section concludes that none of these arguments is clearly directed by text or history, and that none of these theories has received unequivocal support from the Supreme Court.

\section{The Eleventh Amendment Explanation for Sovereign Immunity's Jurisdictional Status}

The language of the Eleventh Amendment, providing that "the judicial power of the United States shall not be construed to extend . .." appears clearly intended, whatever else it may do, to alter the scope of Article III. To that extent it creates a jurisdictional restriction on the power of the federal courts as it existed prior to the amendment. Nevertheless, the literal text of the Eleventh Amendment sets up a very limited jurisdictional

85. See id. at 84 (Stevens, J. dissenting) ("Hans ... reflects, at the most, this Court's conclusion that, as a matter of federal common law, federal courts should decline to entertain suits against unconsenting States.").

86. 527 U.S. $706(1999)$

87. 517 U.S. at 69 . 
bar, prohibiting federal courts from hearing only the narrow class of cases in which a citizen of one state sues another state. Some scholars have viewed the amendment as having an even more restricted meaning, serving only to remove the original Constitution's affirmative grant of diversity jurisdiction in suits against a state by another state's citizens-thus leaving subject matter jurisdiction otherwise intact. ${ }^{88}$

Since Hans, however, the Court has repeatedly held that the Eleventh Amendment possesses a greater significance than its literal text would suggest-that is, it also bars suits against a state by its own citizens. ${ }^{89} \ln$ Hans itself, the plaintiff raised the argument that the literal terms of the Eleventh Amendment did not appear to preclude federal jurisdiction over his suit. As a citizen of the same state against which he brought suit, he argued that from a textual point of view his claim was not barred by the Eleventh Amendment, the language of which applied only to suits by foreign states. ${ }^{90}$

As the Court conceded, "lt is true, the amendment does so read: and if there were no other reason or ground for abating his suit, it might be maintainable."191 The Court argued, however, that this set of affairs would lead to the "anomalous" result that a state could be sued by its own citizens, but not those of other states, under federal question jurisdiction. ${ }^{92}$ The Court rejected such an outcome, finding that it would be "no less startling and unexpected" than the Chisholm decision that had sparked the Eleventh Amendment itself. ${ }^{93}$

The Chisholm majority had erred, the Court suggested, by its "close observance of the letter of the constitution, without regard to former experience and usage." ${ }^{94}$ Citing passages from Federalist No. 81, ${ }^{95}$ the Court argued that, at the time the original Constitution was ratified, "[a]ny such power as that of authorizing the federal judiciary to entertain suits by individuals against states had been expressly disclaimed" by the ratifying

88. See Historical Interpretation, supra note 18 at 1060-61.

89. See Alden, 527 U.S. at 713 ("[T] [Te sovereign immunity of the States ... is [not] limited by ... the terms of the Eleventh Amendment.").

90. Hans v. Louisiana, 134 U.S. 1, 10 (1890).

91. Id.

92. Id.

93. Id. at 11 .

94. Id. at 12 .

95. The Court stated:

It is inherent in the nature of sovereignty not to be amenable to the suit of an individual without its consent. This is the general sense and the general practice of mankind;... [u]nless, therefore, there is a surrender of this immunity in the plan of the convention, it will remain with the States.

Id. at 13 (citing The Federalist No. 81 Alexander Hamilton) (emphasis omitted). As a historical matter, the significance of Hamilton's argument, and the extent to which it reflected widely shared beliefs, have been much disputed. See Seminole Tribe v. Florida, 517 U.S. 44, 100 (1996) (Souter, J., dissenting). 
states. ${ }^{96}$ As a result, it would be "an absurdity" to conclude that "when the Eleventh Amendment was adopted, it was understood to be left open for citizens of a State to sue their own state in the federal courts." 97 Thus, the Court suggested, to allow a suit such as Hans's to proceed would be to repeat the Chisholm court's error and "strain the Constitution and the law to a construction never imagined or dreamed of."98

While this reasoning rests heavily on a theory of original intent, it fails to make clear whose intent is relevant-that of the Constitution's drafters or the Eleventh Amendment's. Nor is it clear where, as a textual matter, this intent is manifested in the Constitution's language. The Court further complicated matters by resting its holding on an alternative, purely statutory ground. ${ }^{99}$

Hans's result did not, therefore, rest explicitly or necessarily on the scope of Article III's jurisdictional grant. Nevertheless, the Hans Court expressly cast its holding as mandated by a limit on the federal "judicial power." 100 As a result, Hans has come to stand for the view that the Eleventh Amendment, by some nonspecific mechanism, removed all suits against states, not merely those mentioned in its text, from the purview of Article III. ${ }^{101}$

As the following section explains, a more charitable reading of Hans is possible. Nevertheless, the Court has at times arrived at a jurisdictional understanding of sovereign immunity by embracing this somewhat farfetched understanding of the Eleventh Amendment's text. Justice Powell, for example, once argued that the Eleventh Amendment removed from the judicial power, "in language that could not be clearer," suits commenced "against one of the United States." 102 Justice Rehnquist's majority opinion in Seminole Tribe v. Florida described the Eleventh Amendment's operation in similar terms, speaking of "the background principle of state sovereign immunity embodied in the Eleventh Amendment" and asserting that " $\mathrm{t}] \mathrm{he}$ Eleventh Amendment restricts the judicial power under Article III." 103 Such passages appear to rest on the view that the Eleventh

96. Hans, 134 U.S. at 12.

97. Id. at 15 .

98. Id.

99. The Court found that the statutory grant of federal question jurisdiction did not extend to suits that state courts had no power to hear-and that since states enjoyed immunity in their own courts, federal courts had no statutory authority to entertain suits against them. Id. at 18-19.

100. Id. at 15 .

101. See, e.g., Seminole Tribe v. Florida, 517 U.S. 44, 72 (1996)

102. Patsy v. Bd. of Regents, 457 U.S. 496, 525 (Powell, J., dissenting). Although Powell wrote in dissent, his reasoning here is significant for two reasons. First, the views Powell expressed in his Patsy dissent found their way into his majority opinions in other cases, most significantly in Pennhurst State Sch. \& Hosp. v. Halderman. See 465 U.S. 89, 98 (1984). Additionally, there are legitimate questions about whether Patsy's majority opinion is still good law. See Mascheroni v. Bd. of Regents, 28 F.3d. $1554,1557-59$ (10th Cir. 1994).

103. Seminole Tribe, 517 U.S. at $72-73$. 
Amendment did not simply remove an offending phrase from Article III but added a more general prohibition to the constitutional text that previously did not exist.

Lower courts have frequently stated even more baldly the view that a general sovereign immunity bar exists somewhere, somehow, within the Eleventh Amendment. A recent district court case, for example, cited Edelman v. Jordan ${ }^{104}$ and Hans in support of the proposition that the Eleventh Amendment "not only prohibits suits against states brought by citizens of other states in federal court, but, implicitly, suits against a state in federal court brought by its own citizens." 105

Because the textual foundations of this view are weak-making the Eleventh Amendment appear to be a particularly poor piece of drafting-it has been abundantly criticized. Akhil Reed Amar, for example, has characterized this view of sovereign immunity as resting on the argument that "[t]he defect of Chisholm was its failure to recognize absolute state sovereign immunity from citizen suits in all circumstances, and this defect was corrected by enshrining such immunity in the Constitution." 06 Amar calls this view "nonsense," because it ignores the unambiguously limited reach of the Eleventh Amendment's language. ${ }^{107}$ Other commentators have made the same criticism. ${ }^{108}$

The view that state sovereign immunity derives from the Eleventh Amendment lacks support in the amendment's drafting history as well as its text. There is no indication that the amendment was intended to have jurisdictional effects. In fact, some evidence exists to the contrary: a version of the amendment that would have introduced an explicit prohibition against state party defendants was introduced and rejected in Congress. ${ }^{109}$ Moreover, this view fails to explain why state sovereign immunity does not conform to the ordinary rules of Article III jurisdiction. Dissenting in Patsy v. Board of Regents, Justice Powell attempted to explain one of sovereign immunity's nonjurisdictional aspects, the possibility of waiver, by suggesting that, reflecting historical practice, the jurisdictional bar imposed by the Eleventh Amendment applies only to suits against nonconsenting states. ${ }^{\text {i }} 10$ However, while this proviso makes the jurisdictional view of sovereign immunity less problematic doctrinally, it also takes it still farther from constitutional text. Justice Powell's view requires reading into the Eleventh

\footnotetext{
104. 415 U.S. 651 (1974).

105. McGregor v. Goord, 18 F. Supp. 2d 204, 206 (N.D.N.Y. 1998).

106. Akhil Reed Amar, Of Sovereignty and Federalism, 96 YALE L.J. 1425, 1473 (1987).

107. See id. at 1473-75.

108. See, e.g., Erwin Chemerinsky, Against Sovereign Immunity, 53 Stan. L. Rev. 1201, 1205 (2001).

109. See Historical Interpretation, supra note 18 at 1058; see also Nelson, supra note 18, at 1603-

110. See Patsy, 457 U.S. at 528 n.13.
} 04. 
Amendment not only a broad jurisdictional principle but an exception to that principle where consenting states are concerned.

In some respects, the argument that Justice Powell's view lacks internal logic or historical support parallels commentators' more general criticisms of the post-Seminole Tribe revolution ${ }^{11}$ in state sovereign immunity doctrine. ${ }^{12}$ Yet even as Seminole Tribe has become entrenched, the view of sovereign immunity as a jurisdictional doctrine "embodied" in the Eleventh Amendment has to some extent fallen out of favor. ${ }^{113}$ Indeed, as discussed in Part II infra, in some ways the Court has made this view less plausible by expanding the scope of state sovereign immunity into areas-such as suits in state court - that have nothing to do with federal jurisdiction at all.

As it stands, then, the view of the Eleventh Amendment as an affirmatively jurisdiction-limiting mechanism is a perplexing anomaly: the Court continues to rely upon it from time to time, ${ }^{114}$ and lower courts therefore cannot ignore it. Yet this view is almost embarrassingly lacking in textual support and is out of step with the direction of current state sovereign immunity doctrine. Perhaps as a result, Justice Kennedy in his Alden v. Maine opinion recently joined sovereign immunity skeptics in rejecting the notion that sovereign immunity "derives from" the Eleventh Amendment. ${ }^{115}$ It remains to be seen whether the Court will unanimously or consistently adhere to Justice Kennedy's position, which would substantially call into question the reasoning in many still-foundational state sovereign immunity opinions. ${ }^{116}$ Nevertheless, the Court's willingness to consider alternatives

111. This "revolution" consists of the Court's holding, in Seminole Tribe and subsequent cases, that Congress could not abrogate state sovereign immunity pursuant to its Article I powers. See Seminole Tribe v. Florida, 517 U.S. 44 (1996); Vicki Jackson, Seminole Tribe, the Eleventh Amendment, and the Potential Evisceration of Ex parte Young, 72 N.Y.U. L. REv. 495 (1997).

112. See, e.g., Unfinished Business, supra note 3, at 857-58 (arguing that "all nine justices have abandoned any thought, or any pretense, that the text of the Eleventh Amendment matters" and that the Court has failed to grapple with "the hard work of translating [state sovereign immunity] into a workable federal structure").

113. See Alden v. Maine, 527 U.S. 706, 713 (1999) (clarifying that, despite any suggestions to the contrary in earlier opinions, "the sovereign immunity of the States neither derives from, nor is limited by, the terms of the Eleventh Amendment"). See also Blatchford $v$. Native Village of Noatak, in which Justice Scalia, writing for the majority, notes that:

[W] have understood the Eleventh Amendment to stand not so much for what it says, but for the presupposition of our constitutional structure which it confirms: that the States entered the federal system with their sovereignty intact; and that the judicial authority in Article 111 is limited by this sovercignty.

501 U.S. 775, 779 (1991).

114. For example, simply by its frequent use of the words "Eleventh Amendment" as shorthand for "state sovereign immunity," the Court continually implies-as Justicc Kennedy's Alden opinion acknowledged-the view that sovcreign immunity inheres in the Eleventh Amendment itself. Alden, 527 U.S. at 713.

115. Id.

116. In fact, it seems unlikely that the Court will do so. Justice Kennedy himself has slipped back into the Eleventh Amendment theory from time to time. See, e.g., Frew v. Hawkins, 124 S. Ct. 899, 903 
to the Eleventh Amendment theory of state sovereign immunity suggests the view's inadequacies in explaining current sovereign immunity doctrine.

\section{The Article III Explanation for Sovereign Immunity's Jurisdictional Status}

In recent years, commentators have attempted to develop a more tenable conception of sovereign immunity's jurisdictional nature by arguing that state sovereign immunity should be understood as inhering in the language of Article III itself-in the notion of the "judicial power," perhaps, or in the definition of "cases" and "controversies"-rather than in some nonspecific Eleventh Amendment penumbra. According to this view, sovereign immunity doctrine, like the justiciability criteria encompassed in the "case or controversy" requirement of Article III, has from the beginning been rooted in the text of the Constitution. ${ }^{117}$ Because the Chisholm court failed to recognize this point, the argument goes, the Eleventh Amendment was needed to perform two functions. First, it removed the constitutional language interpreted by the Court in Chisholm to authorize foreign-citizen suits against states. Second, it expressed a more general disapproval of the Chisholm court's view that no principle of sovereigu immunity survived constitutional ratification. ${ }^{118}$ Under this view, the amendment did not so much import a new principle of sovereign immunity into the Constitution as direct the Court to recognize an already existing limit.

Some modern commentators have sought to rehabilitate sovereign immunity as a textually based doctrine by means of this argument, ${ }^{119}$ and the early Eleventh Amendment cases provide them with some support. The Hans court's argument that "this court has often declined to take jurisdiction" of "controversies ... which, on the settled principles of public law, are not subjects of judicial cognizance," 120 appears to have relied partly on the principle that the word "controversy" contains certain understood limitations. In re State of New York, a I921 case holding that a state may not be sued in actions in admiralty, referred to sovereign immunity as "a fundamental rule of jurisprudence ... bearing upon the construction of the Constitution" to such an extent that "it has become established by repeated decisions of this court that the entire judicial power granted by the

(2004) ("The Eleventh Amendment confirms the sovereign status of the States by shielding them from suits by individuals absent their consent.").

117. See Nelson, supra note 18 , at 1567-68, for one version of this theory. It should be noted that Nelson's argument-which relies on specific historical evidence about the meaning of "cases" and "controversies"-is far more textually specific than any Supreme Court case has been.

118. See, e.g., id. at 1603-04 (arguing that the Eleventh Amendment's phrasing may have been chosen deliberately to alter "the very grants of subject matter jurisdiction on which members of the Chisholm majority had relied").

119. See id. at 1564-65 (arguing that commentators have overlooked evidence that Artiele lll's text, as originally understood, included a principle of state sovereign immunity).

120. 134 U.S. 1, 15 (1890). 
Constitution does not embrace authority to entertain a suit brought by private parties against a state without consent given." 121 Principality of Monaco v. Mississippi, ${ }^{122}$ a 1934 case holding that a foreign state could not subject an American state to suit, also suggests an analogy between justiciability requirements and sovereign immunity as implied limitations on Article IIl powers:

Behind the words of the constitutional provisions are postulates which limit and control. There is the essential postulate that the controversies, as contemplated, shall be found to be of a justiciable character. There is also the postulate that States of the Union, still possessing attributes of sovereignty, shall be immune from suits, without their consent. ${ }^{123}$

This passage, of course, stops short of stating explicitly that sovereign immunity is inherent in the language of Article III. Nevertheless, the Court indicates, at the very least, that sovereign immunity and justiciability requirements operate in strikingly similar ways. Moreover, the Monaco Court elsewhere finds that the requirement of state consent to suit is "implied" in Article III, ${ }^{124}$ suggesting that the Court's reasoning is founded in Article III's text itself.

The result in Chisholm, however, complicates the view that sovereign immunity limits the "judicial power" or the nature of "cases or controversies" since the Chisholm court found no such implied limitation in the constitutional text. ${ }^{125}$ Its advocates, therefore, have seen the Eleventh Amendment as, at the very least, an indication that the Chisholm court got it wrong, and, perhaps, as a direction to the judiciary about how the Constitution should be interpreted in the future. Hans provides some support for the view that the Eleventh Amendment "overruled"126 and "actually reversed" 127 the Court's decision in Chisholm. Hans suggests that, by framing the amendment as a direction not to "construe" the judicial power in a certain way - a command seemingly aimed squarely at the courts - the drafters and ratifiers of the Eleventh Amendment "did not redefine the federal judicial power but instead overruled the Court."128 In other words, the Eleventh Amendment enshrined a specific method of constitutional interpretation, under which the permissible reach of the judicial power did not encompass suits against the state. ${ }^{129}$

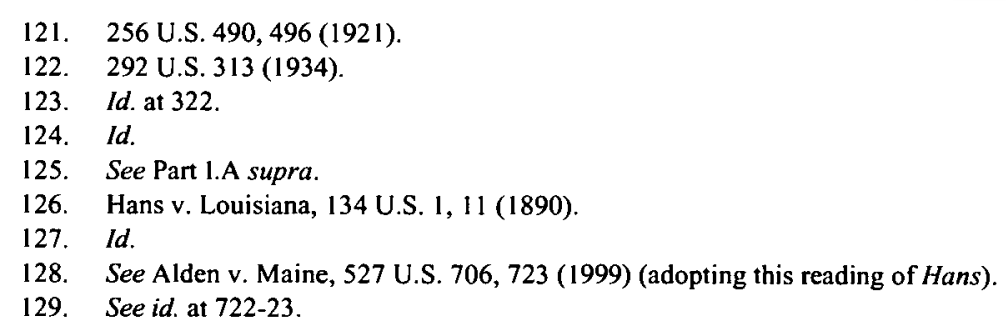


While perhaps a plausible reading of both Hans and the Eleventh Amendment, this theory is not without its own difficulties. Insofar as it is textually rooted, it relies largely on vague understandings and implications that depend on a certain historical view of Article III, the Eleventh Amendment, and Hans-a view that is, in fact, fiercely contested. ${ }^{130}$ Moreover, although it has used language that in some cases seems compatible with the Article III theory, the Supreme Court has generally suggested that it is the Eleventh Amendment itself, not Article III as adopted in 1787 , that constitutionalizes sovereign immunity as a limit on the judicial power. ${ }^{131}$

Indeed, the Court recently rejected explicitly the idea that the Eleventh Amendment poses a limit on Article III's terms in the same way that justiciability requirements do. In Calderon v. Ashmus, ${ }^{132}$ the Court concluded that before it could address a sovereign immunity claim, it was first obliged to determine an antecedent jurisdictional question: whether the particular sort of declaratory judgment sought constituted an Article III "case or controversy." 33 Explaining this order of proceeding, the Court observed in a footnote that "[w]hile the Eleventh Amendment is jurisdictional in the sense that it is a limitation on the federal court's judicial power, and therefore can be raised at any stage of the proceedings, we have recognized that it is not coextensive with the limitations on judicial power in Article III." 134 The Court thus suggested that the "judicial power" discussed in cases such as Hans and Monaco is not the same thing as the "judicial power" referenced in the text of Article III. If this is true, it weakens-or at least substantially complicates-the case that sovereign immunity derives from the Constitution's text.

Calderon points to a further problem with the Article III theory: its sheer vagueness. Insofar as a background constitutional principle of state sovereign immunity exists, the theory does not explain why it takes the particular character it does-why it should be discovered in the words of Article III rather than elsewhere in the Constitution, for example, or why it should be understood as an absence of jurisdiction rather than an

130. The four consistent dissenters in recent sovereign immunity cases-Justices Breyer, Ginsburg, Souter, and Stevens-have regarded state sovereign immunity as a common law doctrine subject to unrestricted congressional abrogation, and do not view Hans as holding to the contrary; for the most sustained elaboration of this view, see Justice Souter's dissent in Seminole Tribe v. Florida, 517 U.S. 44, 100 (1996). Many scholars also maintain that, as a matter of historical interpretation, the idea that Article 111 originally embodied a principle of sovereign immunity is incorrect. See, e.g., Gibbons, supra note 57 at 1893-94.

131. See Part l.B.l supra.

132. 523 U.S. 740,745 (1998).

133. Id. at 745, n.2.

134. Id. (citing ldaho v. Coeur d'Alene Tribe of Id., 521 U.S. 261, 267 (1997); Patsy v. Board of Regents of Fla., 457 U.S. 496, 515, n. 19 (1982)) 
affirmative defense. ${ }^{135}$ As will be discussed in Part II infra, the Supreme Court has in fact recently relied on an alternative view of the doctrine that is founded in beliefs about state sovereignty itself and that suggests that the immunity does not limit the "judicial power" so much as the federal government more generally. Because the Article III theory relies on broad implications from constitutional text rather than specific constitutional language, there is no obvious reason-nor has the Supreme Court articulated one - to prefer it over the state sovereignty view or, indeed, any number of other competing interpretations.

A final problem with the Article III theory is that it is not necessarily compatible with current sovereign immunity doctrine. As one expositor of the theory has noted, this interpretation of state sovereign immunity suggests a two-tiered view: on the one hand, an explicit bar against foreigncitizen suits that is jurisdictional and absolute; on the other, a background understanding potentially subject to congressional redefinition. ${ }^{136}$ Indeed, by suggesting a textual distinction between two kinds of state sovereign immunity cases - those brought by foreign citizens and those brought by a state's own citizens - the Article III view suggests that the two types of sovereign immunity are doctrinally distinct as well. Yet this view does not prevail in the Court's current jurisprudence. ${ }^{137}$ The Article III view may thus raise more doctrinal problems than it resolves.

As a result of these complications, it is difficult to see the Article III view as demanded by constitutional text or surrounding history. At best, it is a possible (and, at that, highly contested) theory of how the Eleventh Amendment's drafters might have read Article III's language. It is not, however, the sole or even the obvious interpretation. Moreover, it is not a view that the Court has ever explained at length or adhered to consistently.

\section{The "Nature of Sovereign Immunity" Explanation for Sovereign} Immunity's Jurisdictional Status

A final possible explanation for the jurisdictional notion of sovereign immunity, focusing on functional similarities between sovereign immunity and jurisdiction, is less an argument than an assumption, and can be considered more briefly than the other theories. Although this explanation has rarely been developed at length, courts and commentators have

135. Of course, the two concepts may be seen as mirror images of each other. In Puerto Rico Aqueduct \& Sewer Authority v. Metcalf \& Eddy, Inc., for example, the Court noted that the "[Eleventh Amendment's] withdrawal of jurisdiction effectively confers an immunity from suit." 506 U.S. 139, 144 (1993). Nevertheless, this equivalence does not work both ways: the assertion of an immunity in other contexts is not the same thing as a challenge to the court's jurisdiction. See ITS! TV Prods., Inc. v. Agric. Assoc., 3 F.3d 1289, 1292 (9th Cir. 1993).

136. See Nelson, supra note 18 , at 1615.

137. Id. at 1623-24 (noting, for example, that the Court has allowed Congress to abrogate state sovereign immunity in lawsuits brought against states by citizens of other states). 
occasionally assumed that state sovereign immunity is jurisdictional largely because of the manner in which it operates. ${ }^{138}$ That is, because a successful assertion of sovereign immunity is an absolute defenseautomatically barring a court from hearing a claim regardless of the circumstances ${ }^{139}$-its function is different from that of an ordinary affirmative defense, which may allow the defendant to escape liability only to a certain extent or under particular conditions. ${ }^{140}$ The successful assertion of a sovereign immunity claim thus operates in a manner similar to a finding of a jurisdictional defect, which also requires immediate dismissal. Thus, some courts have concluded, sovereign immunity is jurisdictional because it works in a jurisdictional way.

This habit of equating immunity and jurisdiction in general is widespread, not just in Eleventh Amendment opinions but in courts' treatment of the immunity of other sovereigns. Courts often describe the sovereign immunity of the United States, of Indian tribes, and of foreign nations in jurisdictional terms, despite the fact that none of these doctrines (with the possible exception of the immunity of the United States) is constitutionally rooted and all are subject to unlimited modification by Congress. ${ }^{141}$ All, however, have the jurisdiction-like effect of mandating dismissal of the claim in which they are asserted.

However, the comparison between state sovereign immunity and the immunities of other sovereigns, while intriguing, ultimately does more to undermine the jurisdictional case than to bolster it. Immunities such as those granted to foreign nations and tribes are not constitutionally founded; they exist because Congress chooses to recognize them as an attribute of sovereignty, not because they are mandated by the Eleventh Amendment or Article III. Insofar as the Supreme Court has suggested that the special properties of state sovereign immunity derive from its constitutional origins, taking the analogy between state sovereign immunity and other

138. See In re Stock Exchs. Options Trading Antitrust Litig., 317 F.3d 134, 152 (2d Cir. 2003) (recognizing distinctions between immunity and jurisdiction in general while also referring to several cases in which "a government's sovereign immunity. . has frequently been referred to as imposing constraints that are jurisdictional").

139. See Fed. Mar. Com'n v. S.C. State Ports Auth., 535 U.S. 743, 766 (2002) ("Sovereign immunity does not merely constitute a defense to monetary liability or even to all types of liability. Rather, it provides an immunity from suit.").

140. Discussing the immunity possessed of cabinet officials, for example, the Court noted that "the essence of absolute immunity is its possessor's entitlement not to have to answer for his conduct in a civil damages action." Mitchell v. Forsyth, 472 U.S. 511, 525 (1985); see also Kirsten Matoy Carlson, Note, Towards Tribal Sovereignty and Judicial Efficiency: Ordering the Defenses of Tribal Sovereign Immunity and Exhaustion of Tribal Remedies, 101 MicH. L. REv. 569 (2002) (discussing similarities among state sovereign immunity, tribal sovereign immunity, and jurisdictional considerations).

141. See Alaska v. United States, 64 F.3d 1352, 1355-56 (9th Cir. 1995) (discussing broad exccptions to federal immunity carved out by Congress); William C. CANBY, AMERICAN INDIAN LAW IN A NuTSHELl 87-95 (3d ed. 1998) (discussing nature of Indian tribal immunity). 
immunities too far would call into question the entire Hans/Seminole Tribe line of reasoning. ${ }^{142}$ If all immunities are jurisdictional, then the concept of immunity has little meaning and, because of the potential for confusion with Article III or other forms of subject matter jurisdiction, should simply be avoided.

Ultimately, as a justification for the jurisdictional view of sovereign immunity, the argument based on the nature of immunity is at best incomplete. The fact that sovereign immunity is in some respeets like jurisdiction does not require the conclusion that it is in fact jurisdictional. Even if one were to make the determination solely by comparing similarities, state sovereign immunity and jurisdictional requirements are more different than alike. This is true not only because of the many exceptions to sovereign immunity already enumerated, but also because of differences in the way sovereign immunity and jurisdictional requirements work procedurally. For example, the vast majority of courts require the state to plead and prove sovereign immunity claims ${ }^{143}$; by contrast, the party seeking to invoke federal jurisdiction must assert and prove its existence. In light of such differences, the Court in Wisconsin Department of Corrections v. Schacht cautioned against carrying an analogy between state sovereign immunity and Article III jurisdictional requirements too far. ${ }^{144}$ If all immunities are jurisdictional, then the concept of immunity has little meaning and, because of the potential for confusion with Article III or other forms of subject matter jurisdiction, should simply be avoided.

Moreover, there is an element of question-begging in all functional explanations for the jurisdictional view. In reality, the practical consequences of introducing a state sovereign immunity defense in court depend on the extent of the protection the doctrine provides-which in turn depends on what, precisely, the doctrine is. It is not enough, therefore, to argue that state sovereign immunity is jurisdictional because it functions in the same manner as jurisdiction; it must first be shown why sovereign immunity should function that way in the first place. ${ }^{145}$

142. In addition, lower courts have in some cases treated the various immunities differently, affording more protcction to states than to other immune sovereigns. See, e.g., Alaska, 64 F.3d at 1355 (holding that whilc a denial of state sovereign immunity is an immediately appealable collateral order, a denial of federal sovereign immunity is not). This special status might be called into question were the immunities of all sovereign entities to be equated.

143. See infra note 234 .

144. See Wis. Dept. of Corr. v. Schacht, 524 U.S. 38 I, 388-89 (1998) (finding an analogy between an absence of diversity jurisdiction and the presence of a state sovereign immunity claim "unconvincing" because "[t]he Eleventh Amendment... does not automatically destroy original jurisdiction").

145. This is not to say that these functional arguments cannot have some role in defining state sovereign immunity; indecd, this Comment's argument that state sovereign immunity is nonjurisdictional (and, more particularly, that it is best characterized as an immunity or defense) is based in part on its functional characteristics. Jurisdictional doctrines, however, are not merely functional descriptions of how courts operate; they are substantive limits on courts' powers that 
The functional similarities between state sovereign immunity and jurisdiction are nevertheless significant. Indeed, they may serve to explain the Supreme Court's use of jurisdictional terms in Eleventh Amendment and other sovereign immunity cases, since the language of jurisdiction is convenient shorthand for describing certain ways in which sovereign immunity operates. These similarities alone, however, cannot justify treating state sovereign immunity as jurisdictional. As will be discussed briefly in Part IV infra, other ways of conceptualizing state sovereign immunity can also explain its jurisdiction-like properties.

This Part has argued that no explanation for sovereign immunity's jurisdictional status is fully satisfactory or comprehensive. Part II considers the ways in which the Court's development of sovereign immunity doctrine has put additional pressures on the jurisdictional view. ${ }^{146}$ Beginning with a discussion of the Young exception to state sovereign immunity, it argues that Young doctrine has evolved from a strict jurisdictional loophole to a more flexible test that allows courts to weigh the strength of the federal interests involved. Part II then proceeds to consider the ways in which nonEleventh Amendment theories of sovereign immunity, which have recently gained ascendancy in the Supreme Court, undermine the jurisdictional view. Finally, the next section argues that the Supreme Court has persistently characterized sovereign immunity in nonjurisdictional as well as jurisdictional terms, thus fostering continuing doubt about whether the jurisdictional view is an accurate way of understanding the doctrine.

\footnotetext{
normally derive from an external source (i.e., the Constitution or statutes). Therefore, to characterize state sovereign immunity as jurisdictional is not mercly to describe how it works. It is also to suggest that it does and should serve as a meaningful substantive limit on a federal court's underlying authority.

146. This discussion does not consider all aspects of sovereign immunity doctrine that are incompatible with the jurisdictional view. The congressional power to abrogate sovereign immunity under the Fourteenth Amendment's enforcement clause, for example, has no parallel in any other Article Ill doctrine; similarly, states can waive their sovereign immunity even though defects in subject matter jurisdiction cannot generally be cured by consent. See CHEMERINSKY, supra note 23, at 399. Moreover, issues of waiver and abrogation have been fiercely contested in recent years and have been the subject of many Supreme Court decisions. See generally Bohannan, supra note 49. Yet while these doctrines may be anomalous given an Article III view of state sovereign immunity doctrine, they have not been debated primarily in jurisdictional terms. The question of abrogation, for example, has focused since Seminole Tribe on the extent of Congress's powers under the Fourteenth Amendment, not on an interpretation of the Eleventh Amendment or Article 111. See ChEMERINSKY, supra note 23, at 444-46. (Seminole Tribe's holding-that the Fourteenth Amendment is the exclusive source of congressional power to abrogate sovereign immunity - does not require a jurisdictional view of sovereign immunity, though it is compatible with one.) Therefore, while these doctrines are discussed in passing as they relate to the argument, they are not examined at length.
} 
II.

\section{Pressures on the Subject Matter Jurisdiction View of SOVEREIGN IMMUNITY}

Notwithstanding the Supreme Court's intermittent characterization of sovereign immunity as a doctrine of Article III jurisdiction, the Court has never embraced all the implications of the jurisdictional view. If sovereign immunity were like other forms of subject matter jurisdiction, it could not be conferred by consent, courts would be obliged to raise it on their own motion, and it would apply regardless of whether the relief sought were prospective or retrospective. ${ }^{147}$ At the same time, it would in other respects be narrower in scope: it would have no effect on the powers of state courts, ${ }^{148}$ and it might be more readily subject to congressional abrogation. ${ }^{149}$ The existence of these peculiarities is thus in continual tension with the Article III jurisdiction view. Perhaps as a result, the Supreme Court has characterized the doctrine as jurisdictional only intermittently and has often described sovereign immunity in ways that are clearly incompatible with the jurisdictional view. Moreover, as the Court has elaborated and extended some of the distinctive characteristics of state sovereign immunity, it has eroded the jurisdictional view still further. This section describes that process.

\section{A. The Move Toward a Balancing Approach in Ex parte Young Doctrine}

Notwithstanding Hans's notion of state sovereign immunity as potentially jurisdictional, the Court soon began to develop sovereign immunity doctrine in ways that directly undermined this view. Perhaps the most striking example of this phenomenon is the Ex parte Young sovereign

147. It is also worth noting that the Supreme Court does not seem to regard sovereign immunity as a limit on its own appellate jurisdiction. In McKesson Corp. v. Division of Alcoholic Beverages \& Tobacco, 496 U.S. I 8 (1990), the state of Florida had consented to be sued in Florida courts. After the case had made its way to the Florida Supreme Court and plaintiffs failed to obtain all the relief they wanted, they appealed to the United States Supreme Court. The state argued that Supreme Court review of the case was barred by the Eleventh Amendment. Id. at 28 . The Supreme Court disagreed, holding that previous cases on the subject, while few, "uniformly reveal an understanding that the Amendment does not circumscribe our appellate review of state-court judgments" that contain federal issues. Id. at 28. The constitutional structure, the Court found, renders federal law supreme and state court decisions fedcrally reviewable: "State courts must interpret and enforee faith fully the 'supreme Law of the Land," and their decisions are subject to review by this Court," Id. at 29. For an elaboration of this argument, see Vázquez, supra note 69 at 1701-02.

I48. State courts are not, for example, bound by standing rules. See, e.g., Hawkeye Bancorporation v. Iowa Coll. Aid Comm'n, 360 N.W.2d 798, 802 (Iowa 1985).

149. In some respects, Congress has more latitude to define the scope of core jurisdictional restrictions. Congress can, for example, "create a statutory right or entitlement the alleged deprivation of which can confer standing to sue." Warth v. Seldin, 422 U.S. 490, 514 (I975). Similarly, in the area of federal question jurisdiction, the Supreme Court has found that the constitutional grant of jurisdiction should be construed broadly, thus leaving it largely to Congress to define the scope of federal jurisdiction by statute. See CHEMERINSKY, supra note 23, at 264. 
immunity exception. Young doctrine, which began as a formalistic legal fiction theoretically consistent with the jurisdictional view, has increasingly become a complicated test founded on a pragmatic balance between state and federal interests. As a result, courts' application of the Young exception has developed into a complex, fact-bound determination that operates quite differently from Article III inquiries, which require courts to observe precise and sometimes formalistic limits on the federal judicial power.

Among the various exceptions to state sovereign immunity, the principle announced in Ex parte Young is frequently described as the most farreaching and important. ${ }^{150}$ Young doctrine holds that state sovereign immunity does not bar suits for injunctive relief against state officials. In the 1908 case that first clearly articulated the doctrine, Minnesota railroads sued state officials to enjoin the enforcement of rate limits they alleged were unconstitutional. ${ }^{151}$ Despite an Eleventh Amendment defense, the Young Court allowed the suit to proceed, resting its holding on a famous legal fiction. As the Court reasoned, state officials attempting to perform unconstitutional acts or those that violated federal law were acting outside the state's proper sphere of authority, rendering any such act "simply an illegal act upon the part of a state official in attempting by the use of the name of the state to enforce a legislative enactment which is void." 152 Thus the official in such circumstances should be considered "stripped of his official or representative character," 153 and the State "has no power to impart to [the official] any immunity from responsibility to the supreme authority of the United States." 154

This reasoning, even as it created its own logical conundrums, ${ }^{155}$ helped rationalize the exception to make it compatible with the subject matter jurisdiction view of sovereign immunity: because the officials in question no longer represented the state, any jurisdictional prohibition need not apply once the plaintiff had established the officials' unconstitutional conduct. ${ }^{156}$

150. See, e.g., CHEMERINSKY, supra note 23, at 412 (quoting Clyde Jacobs's description of Young as "one of the three most important decisions the Supreme Court . . . has ever handed down").

151. Ex parte Young, 209 U.S. 123, 130 (1908).

152. Id. at 159.

153. Id. at 160 .

154. Id. at $146-47$.

155. The Court in Pennhurst, for example, noted the "well-recognized irony" that, because Young suits generally allege that the official is within the reach of the Fourteenth Amendment and 42 U.S.C. $\S$ 1983 by virtue of being a state actor, "an official's unconstitutional conduct constitutes state action under the Fourteenth Amendment but not the Eleventh Amendment." Peunhurst State Sch. v. Halderman, 465 U.S. 89, 105 (1984).

156. Of course, because under this theory the determination of jurisdiction-that is, whether state sovereign immunity exists-is entirely bound up with the merits of the plaintiff's claim, this distinction means little in any but the most formalistic sense. 
Notwithstanding the seemingly broad applicability of Young, however, the Court has narrowed the scope of permissible suits against state officials. While, as a matter of logic, the legal fiction justification for Young in theory could apply to any situation in which a state official violates federal law, the Court subsequently clarified that the doctrine is subject to several limiting principles. In Ford Motor Co. v. Department of Treasury, for example, the Court held that suits for monetary relief could not be maintained under Young, finding that "when the action is in essence one for the recovery of money from the state, the state is the real, substantial party in interest and is entitled to invoke its sovereign immunity from suit even though individual officials are nominal defendants."'157 In Edelman v. Jordan ${ }^{158}$ and Quern v. Jordan, ${ }^{159}$ the Court refined the Ford principle, holding that litigants suing state officials under Young cannot seek "retroactive" damages for past conduct but can seek an injunction requiring officials to conform future conduct to state law, even if the injunction imposes costs on the state.

The Court's formulation of this retroactive/prospective distinction demanded a new understanding of Young, since the legal fiction that underlies the Young exception-that the official sued is acting outside state authority-would seem equally applicable whether retrospective or prospective relief is involved. ${ }^{160}$ Perhaps the fictional nature of Young doctrine is more immediately apparent when a lawsuit seeks, say, money damages for a past tort rather than simply an injunction directing a specific state official to perform an action; in the first case, the remedy does not involve the offending official at all, and there is thus no separation between the desired remedy and the state itself. Yet it is not entirely clear why Young's logic does not apply in both situations. For example, an injunction directing a state official to pay a discrete sum of money that the state has unlawfully withheld seemingly hews closely to the structure of Young itself, yet the Court has frequently rejected such relief as retrospective. ${ }^{161}$

\footnotetext{
157. 323 U.S. $459,464(1945)$.

158. 415 U.S. 651 (1974).

159. 440 U.S. 332 (1979).
}

160. The Court acknowledges this point in Pennhurst. 465 U.S. at 103 (acknowledging that Edelman cannot be squared with Young's legal fiction, sinee a suit for retroactive monetary relief "[u]nder the theory of Young ... would not be one against the State sinee the federal law allegation would strip the state officer of his official authority").

161. This example is similar to the facts of Edelman, in which plaintiffs alleged that the state had wrongfully failed to pay them federal age and disability benefits under state regulations that were inconsistent with fcderal law. See 415 U.S. at 651 . The Court has rejeeted Young relief even when the claim relates to the ongoing disposition of state funds. In Papasan $v$. Allain, plaintiffs alleged that the State of Mississippi had violated a trust obligation by failing to apply to education federal land grant proceeds that had been specifically designated for the education of Chickasaw children. 478 U.S. 265 , 274. Although plaintiffs argued that the trust obligation was a permanent one and hence not retrospective, the Court disagreed, finding that the claim was barred because the state would have to expend current funds to pay for past misconduct. Id. at 280-81. 
The difficulty of reconciling the prospective/retrospective distinction with Young's doctrinal rationale is compounded by the extraordinary difficulty of applying the distinction in practice. As the Court itself noted, the line between prospective and retrospective relief is rarely one between "day and night." 162 In an attempt to explain why this fuzzy boundary should have the significance it does, the Court in Green v. Mansour suggested that the prospective/retrospective principle is based not on formal considerations, but on a balancing of conflicting forces: on the one hand, concerns underlying sovereign immunity, such as the fear of unexpected drains on the state treasury and the desire to preserve state autonomy; on the other, the need for a mechanism to prevent states from continuing to violate federal law. ${ }^{163}$ Although the Court found that "[b]oth prospective and retrospective relief implicate Eleventh Amendment concerns," it argued that the availability of prospective relief is necessary to serve Supremacy Clause interests, since "[r]emedies designed to end a continuing violation of federal law are necessary to vindicate the federal interest in assuring the supremacy of that law."164 By contrast, "compensatory or deterrence interests are insufficient to overcome the dictates of the Eleventh Amendment." 165 In dissent, Justice Brennan made the obvious rejoinder that the majority had simply formulated a naked balancing test not rooted in constitutional authority. ${ }^{166}$

In subsequent cases, the Court continued to redefine the Young exception as a means of balancing federal and state interests. In Pennhurst State School v. Halderman, for example, the Court again declined to rely on the Young fiction, instead introducing new pragmatic and structural considerations. ${ }^{167}$ In the lower courts, a class consisting of present and potential future residents of Pennhurst, a Pennsylvania institution for the mentally retarded, had sued various state officials responsible for its management, alleging violations of both federal and state law. ${ }^{168}$ The trial court concluded that while no federal law violations had occurred, conditions at

162. Edelman, 415 U.S. at 667; see also Carlos Manuel Vázquez, Night and Day: Coeur d'Alene, Breard, and the Unraveling of the Prospective-Retrospective Distinction in Eleventh Amendment Doctrine, 87 GEo. L.J. 1, $81-82$ (1998) (observing that an order directing a polluter to clean up effluents in a lake can fairly be characterized as both prospective and retrospective under Supreme Court precedents).

163. See Green v. Mansour, 474 U.S. 64, 68-69 (1985); see also Pennhurst, 465 U.S. at 105-06 (describing Edelman as a method of balancing Young's purpose of vindicating federal law with the need to protect sovereign immunity)

164. Green, 474 U.S. at 68.

165 Id.

166. Id. at 77 (Brennan, J., dissenting).

167. 465 U.S. 89 (1984).

168. Id. at 92 
Pennhurst violated a Pennsylvania statute ${ }^{169}$ and on that basis the court issued an injunction requiring detailed remedial procedures. ${ }^{170}$

The Supreme Court reversed, holding that federal courts could not, consistent with the Eleventh Amendment, "order[] state officials to conform their conduct to state law." "71 The Court rested its decision on a frank recognition of the fictional nature of Young doctrine. Noting the "well-recognized irony" that the legal fiction of Young allowed an officer's conduct to constitute state action for purposes of alleging a Fourteenth Amendment violation but not for the purposes of evading sovereign immunity, ${ }^{172}$ the Court rejected the idea that this artificial notion was the true basis for Young's holding. Rather, the Court stated, "Young doctrine has been accepted as necessary to permit the federal courts to vindicate federal rights and hold state officials responsible to "the supreme authority of the United States." 173 Young was thus a means to "harmonize the principles of the Eleventh Amendment with the effective supremacy of rights and powers secured elsewhere in the Constitution"174 and "promote the vindication of federal rights." 175

Nevertheless, the Court found that "the need to promote the supremacy of federal law must be accommodated to the constitutional immunity of the States." 176 In the case at hand, however, there was no "need to reconcile competing interests," since an alleged violation of state law corrected by a federal court "does not vindicate the supreme authority of federal law," but rather constitutes an "intrusion on state sovereignty."177 A view that would permit the suit under Young principles, the Court declared, "rests on fiction, is wrong on the law, and ... would emasculate the Eleventh Amendment." "78 Thus, even as the Court in Pennhurst cast its holding in terms of subject matter jurisdiction, it suggested that Young doctrine derives not from a jurisdictional mandate but a balancing of interests and broadly construed constitutional purposes.

The Pennhurst Court's suggestion, unsurprisingly, has found new advocates among current justices more inclined to see sovereign immunity as a matter of constitutional structure than a specific textual limit. Idaho $v$. Coeur d'Alene Tribe revealed how far some of the current justices are willing to go in reconceptualizing Young as a balancing test. The principal

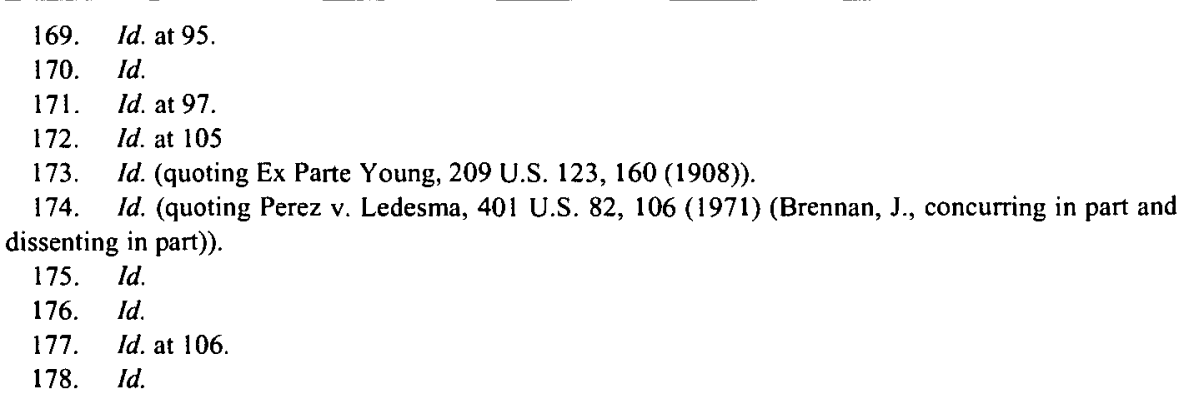


opinion by Justice Kennedy (not joined by a majority of the Court on this point) urged what one commentator has described as a "radical[] revisi[on]" of Young that would render it largely discretionary. ${ }^{179}$ Justice Kennedy argued that courts should allow Ex parte Young suits to proceed only after balancing various factors, including whether a state forum is available to press the claim, whether interpretation of federal law is required, and whether there are "special factors counseling hesitation." $180 \mathrm{He}$ argued further that his approach was grounded in the existing line of Young cases, which, he contended, exhibit a "case-by-case approach"181 and require a "careful balancing and accommodation of state interests when determining whether the Young exception applies in a given case." ${ }^{182}$ With this in mind, he urged that "questions ... as to [Young's] proper scope and application" should be resolved on an individual basis to "ensure that the doctrine of sovereign immunity remains meaningful, while also giving recognition to the need to prevent violations of federal law." 183 This case-bycase approach is, of course, completely inconsistent with Young's original reasoning, which hinged on the argument that suits against state officers acting unlawfully constituted a categorical exception to the principle of state immunity from suit.

Justice Kennedy's views are not shared by a majority of the court; this section of the opinion was joined only by the Chief Justice, with concurring and dissenting justices substantially criticizing Justice Kennedy's approach. ${ }^{184}$ Yet the alternative approaches urged in concurrence relied on a similar, albeit less sweeping, balancing test view of Young. Justice O'Connor, for example, would have decided the case on a narrower exception to Young, finding that the lawsuit was barred because it constituted "the functional equivalent of a quiet title action" and implicated special state sovereignty interests, such as submerged lands. ${ }^{185}$ By suggesting that Young might yield in the face of "special" state sovereignty concerns, she implicitly joined Justice Kennedy's view of Young as a principle the strength of which varies depending on the context in which it is invoked.

Most recently, in Frew v. Hawkins, the Court demonstrated its continuing willingness to consider pragmatic concerns in determining the overall scope of Young doctrine. In Frew, the Court held that the logic of Pennhurst did not extend to federal court orders directing recalcitrant state

179. See Vázquez, supra note 162 , at 42 .

180. See Idaho v. Coeur d'Alene Tribe, 521 U.S. 261, 270, 274, 280 (1997).

181. Id. at 280 .

182. Id. at 278 .

183. Id. at 269 .

184. Id. at 293-94 (O'Connor, J., concurring); id. at 297 (Souter, J., dissenting); see also Vázquez, supra note 162, at 43-44. For example, Justice $O^{\prime}$ Connor, in concurrence, criticized the principal opinion for engaging in a "recharacteriz[ation] and narrow[ing] of much of our Young doctrine." Coeur d'Alene, 561 U.S. at 291.

185. See Coeur d'Alene, 561 U.S. at 289. 
officials to comply with the terms of a consent decree. ${ }^{186}$ Thus, the Eleventh Amendment did not bar federal courts from enforcing compliance with such orders, even when the terms of the consent decree had no clear source in federal law. ${ }^{187}$ In a terse opinion, the Court expended little energy on distinguishing the case from Pennhurst, instead focusing on such factors as courts' need to enforce compliance with their orders ${ }^{188}$ and the fact that the state officials had agreed to the decree to begin with. ${ }^{189}$ At the same time, the Court cautioned federal courts that they should respect state sovereignty interests in enforcing consent decrees, thus ensuring that "responsibility for discharging the State's obligations is returned promptly to the State and its officials." 190 The Court thus treated the issue, which the lower courts and litigants had regarded as primarily one of Eleventh Amendment doctrine, principally in terms of two concerns that are more practical: federal courts' need to enforce their orders and states' desire to act autonomously. The Court's ultimate resolution of the issue-allowing federal courts to enforce their orders, but with sensitivity to state concerns - reflects a balancing process that is miles away from the strict jurisdictional logic of Young.

On the whole, then, the Court has come to treat Young doctrine less as a formal loophole in a jurisdictional provision and more as a pragmatic balancing of the competing interests and demands that exist in a federalist system. Reactions to this development have varied. Some commentators have praised this shift because it allows the Court to take a more flexible, realistic approach to Young cases. ${ }^{191}$ Others have criticized it as an attempt to undermine the important rule-of-law principles Young represents. ${ }^{192}$ The fact that this discussion can take place at all, however-within the Court as well as outside it-suggests that the jurisdictional view has been eroded: the debate is no longer about the extent of the judicial power the Constitution grants, but about the way in which competing interests can best be accommodated. As a result, it is a conversation in which the jurisdictional view appears increasingly irrelevant.

\section{B. The Court's Decreasing Reliance on the Eleventh Amendment}

As many commentators have noted, the Court has frequently advanced versions of sovereign immunity doctrine that rely less on

186. See 124 S. Ct. 899, 904-05 (2004).

187. Id. at 904.

188. Id. at 905 .

189. Id.

190. Id. at 906 .

191. See Vázquez, supra note 162 , at 16.

192. See generally, e.g., John P. LaVelle, Sanctioning a Tyranny: The Diminishment of Ex Parte Young, Expansion of Hans Immunity, and Denial of Indian Rights in Coeur D'Alene Tribe, 31 ARIz. ST. L.J. 787 (1999). 
interpretations of the Eleventh Amendment's text than on inherent structural notions of state sovereignty, federalism, or limited national government. ${ }^{193}$ This strain of Eleventh Amendment doctrine, while part of the Court's analysis ever since Hans, has become increasingly important in recent years, especially in the aftermath of Alden v. Maine,${ }^{194}$ in which the Court extended the sovereign immunity principle to a nonfederal context where Article III plays no role. Because the state sovereignty view, like the subject matter jurisdiction view, reflects a notion of sovereign immunity as a limitation on federal power, it appears on the surface to coexist harmoniously with the subject matter jurisdiction view. At the same time, because the sovereignty theory does not rely on the Eleventh Amendment or Article III at all, it has the potential to undermine the jurisdictional argument.

This "sovereignty/federalism" characterization of sovereign immunity itself comes in several different versions. What might be called the "inherency" view considers sovereign immunity, as a historical matter, to be an essential element of statehood that states possessed at the time they entered the Union. Because the Constitution never explicitly divested them of this power, they retain it. This theory relies on reasoning similar to the sort advanced in key federalism cases such as New York v. United States, ${ }^{195}$ and also rests in part on an interpretation of the Tenth Amendment. ${ }^{196}$

A related, but slightly different, historical argument focuses on sovereign immunity as a background interpretive principle that must inform any reading of the Constitution's text. In other words, since sovereign immunity was widely understood to exist at the time of ratification, and many advocates of ratification argued that sovereign immunity would continue to exist under the new Constitution, the doctrine of sovereign immunity must modify the way in which both Article I and Article III are read. Thus, advocates of this theory argue, the Constitution should be understood as it was during ratification - that is, as failing to grant the federal government powers to subject an unconsenting state to suit. ${ }^{197}$

193. See, e.g., John Allotta, Note, Alden v. Maine: Infusing Tenth Amendment and General Federalism Principles into Eleventh Amendment Jurisprudence, 51 CASE W. RES. L. REV. 505 (2001).

194. 527 U.S. 706 (1999).

195. New York v. United States, 505 U.S. 144 (1992).

196. "The powers not delegated to the United States by the Constitution, nor prohibited by it to the States, are reserved to the States respectively, or to the people." U.S. CoNST., amend. X; see also Alden, 527 U.S. at 714.

197. One commentator, who takes the view that sovereign immunity arises from a historical belief that states were not subject to compulsory process, elaboratcly teases out the implications of this theory. See Nelson supra note 18 at 1629. Nelson notes that Article 1's "necessary and propcr" clause applies both vertically and horizontally - that is, it can be used, respectively, in aid of Congress's Article I powers and in aid of all other federal power, including the judicial power under Articlc III. Id. As a result, assuming sovereign immunity does not function as an affirmative limit on the Article III power, Congress's "horizontal" powers would seem to enable it to subject states to suit. However, an argument can also be made that Congress cannot infer such a sweeping power from gencral constitutional provisions. Id. at $1638-42$. 
A third version, focusing not on constitutional text but constitutional structure, sees the doctrine more pragmatically as an accommodation necessary to maintain the proper balance between state and national power in a federalist system. Some of the Court's reasoning in Pennhurst, in which it discussed Young doctrine as a response to the "need to reconcile competing interests," 198 appeared to rest on its appreciation of "the vital role of the doctrine of sovereign immunity in our federalist system."199 Under this view, sovereign immunity might be seen as akin to other comity-based principles of federal respect for state processes, such as various forms of federal-court abstention. ${ }^{200}$

In practice these theories are very similar and often overlap. ${ }^{201}$ Moreover, as noted, they bear some resemblance to the Article III views already described. Canonical sovereign immunity cases such as Hans-the reasoning of which is vague to begin with - can be read to support the sovereignty view as well as the Article III view.

Nevertheless, the state sovercignty view differs from the Article III view in two important ways. First, it casts state sovereign immunity less as a specific limit on federal jurisdiction than as a structural protection for the states-in other words, as a constraint not on the federal courts per se but on federal power more generally. Second, and relatedly, the state sovereignty idea suggests a notion of sovereign immunity that is potentially less rigid and more subject to judicial balancing than a subject matter principle. This is because, in other contexts, the Court has considered the strength of respective federal and state interests when it polices state sovereigntybased limits on federal power. ${ }^{202}$ For example, while the Court has long accepted the idea that the constitution imposes limits on federal

198. Pennhurst State Sch. v. Halderman, 465 U.S. 89, 106 (1984).

199. Id. at 99 .

200. The state officials in Pennhurst in fact argued that, even if the Eleventh Amendment did not bar the relief granted by the district court, it was prohibited as a matter of comity. Since the Supreme Court found that the Eleventh Amendment did apply, it did not reach this issue. See id. at 97.

201. For the sake of convenience, they are all referred to in the following discussion as "state sovereignty" theories.

202. For example, in National League of Cities v. Usery, 426 U.S. 833, 852 (1976), the Court sought to protect states' most important sovereign functions from federal encroachment, holding that the federal government could not regulate states' "integral operations in areas of traditional governmental functions." Although the Court abandoned this standard in Garcia v. San Antonio Metropolitan Transit Authority, 469 U.S. 528, 556 (1985), it left open the possibility that, in an extreme case, the "constitutional structure" might impose some "affirmative limits... on federal action affecting the States." Similarly, when imposing conditions on states in return for federal grants, Congress must ensure that the eonditions are related to the "federal interest in particular national projects or programs." South Dakota v. Dole, 483 U.S. 203, 207 (1983). Where no federal interest is present, in other words, Congress may not attempt to shape state behavior by furnishing incentives for states to legislate in a certain way. 
interference with inherent aspects of state sovereignty, ${ }^{203}$ it has varied considerably in its assessments of the overall scope of those limits. ${ }^{204}$

Because the Court has come increasingly to rely on the state sovereignty theory in recent years, this view represents a growing challenge to the jurisdictional conception of sovereign immunity. The theory has been particularly effective in providing a theoretical underpinning for the Court's extension of sovereign immunity doctrine beyond its historical contours. The Court's recent sovereign immunity cases have both extended state sovereign immunity doctrine to new areas-such as suits against states in state court ${ }^{205}$ and administrative proceedings against states ${ }^{206}$-and limited its application in some circumstances-for example, by expanding to some degree the notion of waiver. ${ }^{207}$ These developments are more consistent with the more flexible, structure-based state sovereignty theories than with a conception of sovereign immunity as simply a constraint on Article IIl.

The Court's recent opinion in Alden $v$. Maine, written by Justice Kennedy, reflects these developments, advancing the Court's most sustained elaboration of the state sovereignty theory, one that integrates the three versions mentioned above. Like the interpretation put forward by the Hans Court, Kennedy's theory begins with the idea that the Eleventh Amendment operates on the Constitution in a way that is different from other amendments. The text and history of the amendment, he argues, suggest that "Congress acted not to change but to restore the original constitutional design." ${ }^{208}$ In Justice Kennedy's view, the seemingly narrow text of the amendment in fact reflected an ambition broader than that of rejected drafts that would have explicitly enshrined sovereign immunity in the Constitution. Justice Kennedy argues, "Although earlier drafts had been phrased as express limits on the judicial power granted in Article III . . the adopted text addressed the proper interpretation of that provision of the original Constitution ... . By its terms, then, the Eleventh Amendment did not redefine the federal judicial power but instead overruled the Court."209 Thus:

[T] he natural inference is that the Constitution was understood, in light of its history and structure, to preserve the States' traditional

203. See Printz v. New York, 521 U.S. 898 (1997) (federal government may not compel state officers to implement federal programs); New York v. United States, 505 U.S. 144 (1992) (Congress laeks authority to compel states to regulate in a particular area).

204. For example, National League of Cities, 426 U.S. at 852 (1976), was quickly overruled by another 5-4 decision. See Garcia, 469 U.S. at 556 (1985). Each of these decisions reflects a different view of the balance the Constitution strikes between state and federal power.

205. Alden v. Maine, 527 U.S. 706 (1999).

206. Fed. Mar. Comm'n v. S.C. State Ports Auth., 535 U.S. 743 (2002).

207. See, e.g., Lapides v. Bd. of Regents, 535 U.S. 613, 616 (2002).

208. Alden, 527 U.S. at 722.

209. Id. at 723 . 
immunity from private suits. As the Amendment clarified the only provisions of the Constitution that anyone had suggested might support a contrary understanding, there was no reason to draft with a broader brush." 210 Ultimately, then, "sovereign immunity derives not from the Eleventh Amendment but from the structure of the original Constitution itself. ${ }^{211}$

Like Hans, Alden v. Maine speaks of the Eleventh Amendment as being directed at the judicial power. Justice Kennedy's opinion, however, sees the Eleventh Amendment less as a modification of the existing Constitution than as a clarification of its meaning for the benefit of a particularly thickheaded Supreme Court. ${ }^{212}$ ln any case, Justice Kennedy's interpretation vastly diminishes the importance of the Eleventh Amendment, reducing it to, at best, a footnote in a constitutional plan that already embodied a robust sovereign immunity principle. As Justice Souter argued in dissent, in light of Justice Kennedy's analysis, "Seminole Tribe's contorted reliance on the Eleventh Amendment and its background was presumably unnecessary; the Tenth would have done the work with an economy that the majority in Seminole Tribe would have welcomed."213

The Supreme Court's increasing emphasis on state sovereignty has powerful implications for the jurisdictional view, since it means that the Court has ceased to conceive of sovereign immunity as having any explicit basis in either Article III or the amendment that ostensibly alters it. While this unmooring of sovereign immunity doctrine from text itself can be (and has been $)^{214}$ criticized on other grounds, it is in any case difficult to reconcile with any justification for treating sovereign immunity as jurisdictional. If state sovereign immunity is a structural principle, there seems no obvious reason why it should be understood in rigid jurisdictional terms. The Court has found other doctrines rooted in constitutional structure, such as the dormant commerce clause, to be fairly malleable principles that may give way in light of competing interests. Notably, Justice Kennedy, who has written majority opinions or concurrences in several of the Court's recent sovereign immunity opinions as well as Alden, ${ }^{215}$ has expressed strong reservations about the jurisdictional view.

\footnotetext{
210. Id. at 724 .

211. Id. at 728 .

212. A weakness in this view, of course, is that the Eleventh Amendment as enacted seems a peculiarly roundabout way of providing such instruction, since it does not on its face contain any reference to a broader principle of state sovereign immunity.

213. Id. at 761 (Souter, J., dissenting).

214. Unfinished Business, supra note 3, at 857.

215. See Verizon Md., Inc. v. Pub. Serv. Comm'n of Md., 535 U.S. 635 (2002) (concurrence); Bd. of Trs. of Ala. v. Garrett, 531 U.S. 356 (2001) (concurrence); Wis. Dept. of Corr. v. Schacht, 524 U.S. 381 (1998) (concurrence); California v. Deep Sea Research, 523 U.S. 491 (1998) (concurrence); Idaho v. Coeur d'Alene Tribe of ldaho, 521 U.S. 261 (1997) (lead opinion, commanding less than a majority in parts). Justice Kennedy also wrote the majority opinion in the tribal sovereign immunity case, Kiowa Tribe of Oklahoma v. Manufacturing Technologies Inc., 523 U.S. 751 (1998).
} 
Thus, Alden is perhaps the Court's most comprehensive articulation of a theory of sovereign immunity that is basically incompatible with the jurisdictional view. Although it is not clear whether Justice Kennedy's specific beliefs about the nature of sovereign immunity are shared by a majority of the Court, much of Alden's rhetoric of state autonomy and dignity has found its way into subsequent state sovereign immunity opinions. A recent opinion by Justice Thomas, for example, asserted that state sovereign immunity's "preeminent purpose" is to "afford the States the dignity that is consistent with their status as sovereign entities." 216 Whatever the merits of such a view, it shifts the focus of discussion rather dramatically, and portrays sovereign immunity less as a limit on the federal courts' powers than as an affirmative attribute that states possess.

Commentators have routinely decried the Alden view as an unnecessary personalization of states and argued that it has the potential to expand sovereign immunity doctrine beyond its current bounds. ${ }^{217}$ However, should Alden's more free-form analysis ultimately supersede the Article III/Eleventh Amendment theory presented in Hans and Seminole, the effect could ultimately be to shrink the boundaries of sovereign immunity doctrine. In emphasizing the abstract, amorphous concepts of state dignity and sovereign status rather than the strict limits imposed by Article III, the Court appears to be retreating from the jurisdictional view. As a result, Alden and its progeny can easily be read as a directive to federal courts to treat state sovereign immunity as a doctrine that, while important, need not be treated rigidly nor elevated above all other concerns. ${ }^{218}$

\section{Alternative Characterizations of Sovereign Immunity}

If the first two pressures on the jurisdictional theory are purely doctrinal, the third is linguistic as well: the language in which the Court discusses sovereign immunity is frequently inconsistent with a jurisdictional conception. Instead, the Court has invoked a host of alternative characterizations and analogies, suggesting that that sovereign immunity might best be seen as a right, a defense, or a form of personal jurisdiction. Moreover, the Court has used such analogies to explicitly distinguish sovereign immunity from the various forms of subject matter jurisdiction. Indeed, many of the Court's holdings have depended on the observation that sovereign immunity differs from most Article III restrictions. ${ }^{219}$

216. Fed. Mar. Comm'n v. S.C. State Ports Auth., 535 U.S. 743, 706 (2002).

217. See, e.g., Peter J. Smith, States as Nations: Dignity in Cross-Cultural Perspective, 89 VA. L.

Rev. 1 (2003); Suzanna Sherry, States Are People Too, 75 Notre Dame L. Rev. 1121 (2000).

218. Justice Kennedy's Schacht concurrence also provides support for this view. See 524 U.S. 381,394 (1998) (suggesting that courts should consider the fairness consequences of allowing sovereign immunity to be asserted belatedly).

219. See Calderon v. Ashmus, 523 U.S. 740 (1998) 
The Court, moreover, has been remarkably consistent in its inconsistency. Since its decision in Hans, the Court has repeatedly discussed sovereign immunity in terms that suggest a non-jurisdictional as well as a jurisdictional interpretation, often "interchangeably... and in the same opinion."220 Given the inherently absolute, yes-or-no quality of subject matter jurisdiction, this very ambiguity is sufficient to cast doubt on sovereign immunity's jurisdictional status.

Existing alongside the Supreme Court's characterization of sovereign immunity as a jurisdictional limit, for example, has long been a notion that the doctrine simply creates an affirmative defense available to the state to assert if it so chooses. ${ }^{221}$ In Patsy v. Board of Regents of State of Florida, ${ }^{222}$ the Court, in holding that a court need not raise a sovereign immunity issue sua sponte, relied on a conception of the doctrine as a defense. While acknowledging the Court's previous conclusions that the Eleventh Amendment "partakes of the nature of a jurisdictional bar" and that it may be raised by the State for the first time on appeal, ${ }^{223}$ the Court nonetheless observed that: "[B]ecause of the importance of state law in analyzing Eleventh Amendment questions and because the State may, under certain circumstances, waive this defense, we have never held that it is jurisdictional in the sense that it must be raised and decided by this Court on its own motion." ${ }^{224}$ Rejecting the argument for sovereign immunity's jurisdictional status made by Justice Powell in dissent, the Court instead suggested that sovereign immunity operated more as an ordinary affirmative defense.

In subsequent cases, the Court has expanded upon this description of sovereign immunity as a defense. Thus, in Blatchford $v$. Native Village of Noatak, decided prior to the Court's recent decisions limiting Congress's powers to abrogate sovereign immunity, the Court suggested that sovereign immunity may be asserted even after jurisdiction has been found to exist. ${ }^{225}$ Jurisdictional statutes, the Court explained, do not suffice to abrogate sovereign immunity because "[t]he fact that Congress grants jurisdiction to hear a claim does not suffice to show that Congress has abrogated all defenses to that claim." 226 Similarly, in Idaho v. Coeur d'Alene Tribe, the Court, even while acknowledging that the Eleventh Amendment has

220. See Brown, supra note 10 , at 367 .

221. See Charley's Taxi Radio Dispatch v. SIDA of Haw., 810 F.2d 869, 873 (9th Cir. 1987) (noting that " $[t]$ he Eleventh Amendment may be described as cither creating an immunity for states or establishing a jurisdictional limitation on federal courts")

222. 457 U.S. $496(1982)$.

223. Id. at 515 (quoting Edelman v. Jordan, 451 U.S. 651, 687 (1974)).

224. Id.

225. 501 U.S. 775 (1991).

226. Id. at 786-87, n.4 (1991) (emphasis in original); see also 1STl TV Prod., Inc. v. Agric. Ass'ns, 3 F.3d 1289, 1291 (9th Cir. 1991) (treating this passage as support for procedural treatment of sovcreign immunity issues as affirmative defenses). 
jurisdiction-like aspects, specifically held that it was better conceptualized as an immunity:

The grant of federal judicial power is cast in terms of its reach or extent.... The Eleventh Amendment, too, employs the term "extend".... This point of commonality could suggest that the Eleventh Amendment, like the grant of Article III, $\S 2$ jurisdiction, is cast in terms of reach or competence, so the federal courts are altogether disqualified from hearing certain suits brought against a State. This interpretation, however, has been neither our tradition nor the accepted construction of the Amendment's text. Rather, a State can waive its Eleventh Amendment protection.... The Amendment, in other words, enacts a sovereign immunity from suit, rather than a nonwaivable limit on the Federal Judiciary's subjectmatter jurisdiction. ${ }^{227}$

In Wisconsin Dep't of Corrections v. Schacht, ${ }^{228}$ the Court extensively analyzed ways in which the defense-like qualities of sovereign immunity distinguished it from jurisdictional provisions. In Schacht, the appellant argued that the presence of a claim barred by the Eleventh Amendment destroyed jurisdiction to remove a case to federal court, even if another basis for removal existed. ${ }^{229}$ The addition of a nondiverse party destroys federal jurisdiction in a diversity case, the appellant argued; by analogy, the presence of a sovereign immunity claim should destroy jurisdiction in the same way. The Court rejected this argument, explaining that in the diversity case, "The presence of the nondiverse party automatically destroys original jurisdiction: No party need assert the defect. No party can waive the defect or consent to jurisdiction... No court can ignore the defect." $"$ By contrast, "[t]he Eleventh Amendment... does not automatically destroy original jurisdiction," instead granting "a legal power to assert a sovereign immunity defense should it choose to do so. The State can waive the defense."231

Some lower courts have interpreted Schacht as having wide-ranging implications, announcing a "subtle and new direction in Eleventh Amendment jurisprudence"232 that regards the Amendment as "the state's defense to exercise if it chooses." ${ }^{233}$ Even prior to Schacht, however, judicial practice in many circuits was consistent in many ways with viewing sovereign immunity as an affirmative defense. The large majority of

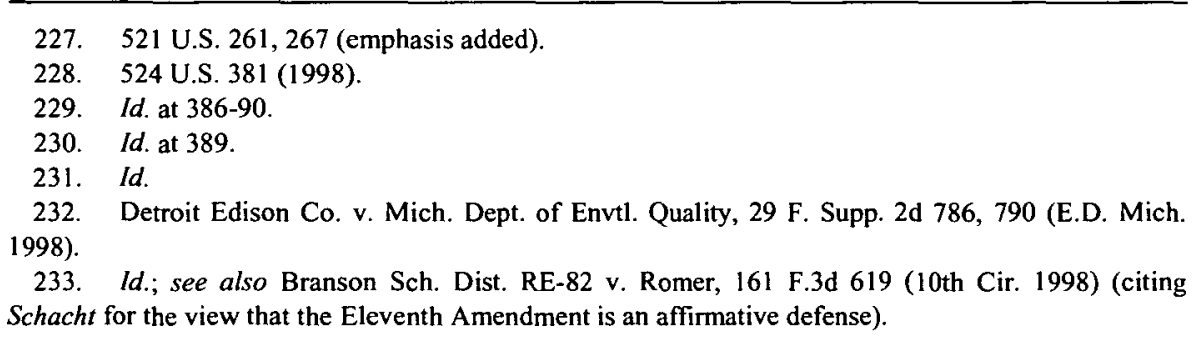


circuits, for example, put the burden of proof on the party asserting sovereign immunity. ${ }^{234}$ By contrast, the party invoking the federal forum has the burden of proving subject matter jurisdiction.

As the scope of sovereign immunity has expanded over the past several years, the Court has increasingly relied on nonjurisdictional characterizations of sovereign immunity to supply guidance. Justice Scalia, writing for the Court in College Savings Bank v. Florida Prepaid Postsecondary Education Expense Board, strikingly analogized sovereign immunity to individual constitutional rights. ${ }^{235}$ While the Court had previously spoken of sovereign immunity as a right belonging to the states, ${ }^{236}$ Scalia carried the analogy further, suggesting that waivers of sovereign immunity, which he described as a "personal privilege,"237 should be regarded in the same light as waivers of other "constitutionally protected privileges."238 Noting that Congress could not, for example, provide that buying or selling securities constituted a waiver of the right to trial by jury in securities fraud cases, he reasoned that a state's mere acceptance of federal funds could not constitute a waiver of sovereign immunity. In either case, such a waiver would not be a "voluntary choice." 239

As one commentator has argued, the Court's "rights" language in Florida Prepaid suggests a far-reaching parallel between state sovereign immunity and a criminal defendant's rights-an equation that, if taken to its logical conclusion, might have the effect of severely limiting the circumstances under which a state can bindingly waive its immunity. ${ }^{240} \ln$ any case, such language takes the Court far afield from the jurisdictional conception of sovereign immunity. By focusing attention not on the federal courts but on the state-and on the degree to which the state acted

234. For cases embracing the affirmative defense view, see Gragg v. Ky. Cabinet for Workforce Development., 289 F.3d 958, 963 (6th Cir. 2002); Skelton v. Camp, 234 F.3d 292, 297 (5th Cir. 2000); Christy v. Pa. Tumpike Comm'n, 54 F.3d 1140, 1144 (3rd Cir. 1995); Baxter by Baxter v. Vigo County Sch. Corp., 26 F.3d 728, 735 (7th Cir, 1994). But see Garcia v. Richard Stockton Coll. of New Jersey, 210 F. Supp. 2d 545, 548 (D.N.J. 2002) (placing burden to show absencc of sovereign immunity on plaintiff on the grounds that sovereign immunity would bar plaintiff's ancillary state law claims); Union Pacific R.R. Co. v. Burton, 949 F. Supp. 1546 (D. Wyo. 1996) (questioning the reasoning of ISTI TV on the grounds that sovereign immunity is jurisdictional).

235. 527 U.S. 666 (1999).

236. Edelman v. Jordan, 415 U.S. 651,673 (1974) (stating, in limiting the circumstances undcr which a state may be deemed to have waived its immunity, that "[c]onstructive consent is not a doctrine commonly associated with the surrender of constitutional rights").

237. College Savings Bank, 527 U.S. at 675 (1999) (citing Clark v. Barnard, 108 U.S. 436, 447 (1883)).

238. Id. at 681 .

239. Id. at 681-82.

240. See Bohannan, supra note 49 at 202-03. The analogy between states' immunity and the rights of a criminal defendant, of course, is not only peculiar-it is difficult to see how a structural "right" like sovereign immunity functions in the same manner as a personal right-but almost perverse, since a defendant's rights in the criminal context serve the very purpose of protecting him against overweening state power. 
intentionally and voluntarily in the conduct alleged to constitute a waiver of sovereign immunity - the conceptualization of sovereign immunity as a "right" reinforces the view that it is not a structural limit on federal judicial power that the courts must self-police but rather a "personal" protection for states that they may assert or dispense with as they wish.

Three days after Florida Prepaid was decided, the Court in Alden $v$. Maine relied on a similar analogy between sovereign immunity and individual constitutional rights. Responding to the dissent's charges that the Alden decision was founded on nothing more than common law or "natural law," the majority observed that "the text and the structure of the Constitution protect various rights and principles," such as trial by jury and the prohibition on unreasonable searches and seizures, that "derive from the common law" but nevertheless have the status of constitutional rights. $^{241}$

A final alternative to the jurisdictional characterization also comes from Justice Kennedy, who recently suggested that sovereign immunity might instead be characterized as a question of personal jurisdiction. While at least one court had earlier treated sovereign immunity as a matter of personal jurisdiction, ${ }^{242}$ Justice Kennedy's concurrence in Wisconsin Department of Corrections $v$. Schach $t^{243}$ appears to be the most extended discussion by a Supreme Court Justice on the subject. Starting with the common observation that the waiver exception is inconsistent with viewing sovereign immunity as a limitation on subject matter jurisdiction, Justice Kennedy noted that, by contrast, "[sovereign] immunity bears substantial similarity to personal jurisdiction requirements." 244 Viewing sovereign immunity as a restriction on subject matter jurisdiction leads, he argued, to unfair results in practice: if a state can raise the Eleventh Amendment for the first time on appeal, it can "proceed to judgment without facing any real risk of adverse consequences." 245 As a solution, Kennedy suggested "modifying our Eleventh Amendment jurisprudence to make it more consistent with our practice regarding personal jurisdiction"-for example, by inferring waiver from a state's failure to timely raise an Eleventh Amendment objection. ${ }^{246}$

This multiplicity of categories suggests that the Court frequently finds the subject matter jurisdiction view inappropriate as a theoretical model. The Court's alternative characterizations call into question the jurisdictional view's viability both by pointing out the ways in which it is a poor fit with the body of state sovereign immunity doctrine and by

241. Alden v. Maine, 527 U.S. 706, 733 (1999).

242. See In re PEAKSolutions Corp., 168 B.R. 918, 922 (Bankr. D. Minn. 1994).

243. 524 U.S. 381,394 (1998) (Kennedy, J., concurring).

244. Id. (Kennedy, J. concurring).

245. Id. (Kennedy, J. concurring).

246. Id. at 395 (Kennedy, J. concurring). 
acknowledging that there are alternative, nonjurisdictional ways in which sovereign immunity can be conceived. The Court's doctrinal uncertainty has thus been reflected in its language, which in turn has also come to undermine the jurisdictional view.

III.

\section{Consequences of the Subject Matter Jurisdiction View of SOVEREIGN IMMUNITY IN LOWER COURTS}

As the previous discussion attempts to show, the Supreme Court has frequently alluded to sovereign immunity as a matter of subject matter jurisdiction, while continuing to develop the doctrine in ways that call that view into question. This inconsistency is of more than theoretical importance. The existence of these essentially irreconcilable perspectives in Supreme Court precedent has created great difficulties for the lower courts. Since federal courts cannot overstep the limits of their subject matter jurisdiction, but also cannot arbitrarily decline to exercise jurisdiction they possess ${ }^{247}$ the question of sovereign immunity's jurisdictional status is an important and urgent issue that lower courts have been obliged to address.

The following section details ways in which circuit courts have sought to reconcile-and have frequently divided over-the Supreme Court's conflicting pronouncements on the jurisdictional status of sovereign immunity. It does not attempt to be a comprehensive list of such issues. ${ }^{248}$ Instead, it looks at the general difficulties lower courts have had in navigating sovereign immunity doctrine, and illustrates them with examples-areas in which the courts have divided most sharply, in which conflict and uncertainty persist, and in which Supreme Court irresolution of sovereign immunity's jurisdictional status has hindered lower courts' ability to decide cases in an even-handed and consistent manner.

The first section focuses on the question of the proper ordering of sovereign immunity and merits issues, and examines the consequences of applying to the sovereign immunity context what might be called the "jurisdictional trump"- the idea that, because jurisdictional issues are fundamental to a court's power to declare the law, the court's priority must be to resolve these issues as soon as possible after they are raised. This section argues that, since state sovereign immunity does not implicate the court's power in the same way that other jurisdictional issues do, the

247. For a vivid formulation of this principle, see Justice Marshall's famous statement in Cohens v. Virginia, 19 U.S. (6 Wheat) 264,404 (1821): "[Courts] have no more right to decline the exercise of a jurisdiction which is given, than to usurp that which is not given. The one or the other would be treason to the Constitution."

248. Many additional uncertaintics exist in important areas of state sovereign immunity doctrine, including, for example, the scope of state waiver and the way in which courts should treat a motion to dismiss on sovereign immunity grounds. 
jurisdictional trump is an inappropriate way for courts to think about the ordering of sovereign immunity and merits questions and has in practice impeded courts' ability to treat litigants fairly and efficiently.

The second section describes how the confusion surrounding state sovereign immunity's jurisdictional status has left courts adrift in areas in which they must apply discretion. Focusing on the question of federal courts' obligations to raise state sovereign immunity issues sua sponte, it contends that the Court's muddled pronouncements about sovereign immunity's jurisdictional status have left lower courts without meaningful guidance in how to assess the competing interests this problem entails.

The final section argues that the Supreme Court's jurisdictional language has often misled lower courts about the correct treatment of sovereign immunity issues. It examines two recent opinions in which the Supreme Court has unanimously reversed a lower court on a state sovereign immunity issue, and suggests that in both cases the lower court's error was, essentially, to take the jurisdictional view too seriously. Because the Court's jurisdictional language has implications that the Court apparently does not intend, this section argues, it is likely to persist in leading lower courts astray. Clarification of current doctrine is thus necessary to avoid continued confusion among both courts and litigants.

\section{A. The Jurisdictional Trump: Steel Co. and Issue Ordering}

As previous sections have discussed, to successfully invoke a limit on a federal court's subject matter jurisdiction is essentially to end all argument. Article III jurisdiction is, under nearly all circumstances, an absolute principle that does not admit exceptions or allow competing concerns to be balanced. Article III absolutism is justified not only by the Constitution's text but also by broader structural concerns about keeping the federal judiciary within bounds, both with respect to state courts and to the other branches of the federal government. Nevertheless, even advocates of limited federal powers frequently concede that addressing these concerns has costs, since the task of policing subject matter jurisdiction may cause the expenditure of substantial judicial resources and create unfairness to individual litigants. ${ }^{249}$ Such costs may be even greater where state sovereign immunity issues are concerned than in other forms of jurisdictional inquiry, since contested state sovereign immunity issues are rarely straightforward, and litigation costs may be particularly high.

The question of whether a court must address state sovereign immunity issues before considering a case's merits illustrates the potentially steep costs of a strict jurisdictional view. The circuits are currently divided on the question of whether the Supreme Court's decision in Steel Co. v.

249. See, e.g., CHEMERINSKY, supra note 23 , at 57-59 (discussing potentially harsh consequences of standing requirements). 
Citizens for a Better Environment obliges them to consider sovereign immunity issues before reaching the merits of a case. In Steel Co., the Court reaffirmed the importance of Article IlI limits by rejecting the practice of "hypothetical jurisdiction." 250 Under the "hypothetical jurisdiction" approach, previously practiced by several circuits, courts decided issues on the merits prior to addressing jurisdictional objections in situations where the merits question could more easily be resolved and where the prevailing party was the same on both issues. ${ }^{251}$ Steel Co., however, held that for a court to pronounce on the merits before establishing its jurisdiction was akin to issuing an advisory opinion; such a practice, the Court concluded, "carries the courts beyond the bounds of authorized judicial action and thus offends fundamental principles of separation of powers." 252 Steel Co. is thus a clear directive to federal courts to take subject matter jurisdiction seriously. For lower courts, it revived a long-standing controversy about whether sovereign immunity is or is not a jurisdictional issue that must precede any consideration of the merits. ${ }^{253}$

In Calderon v. Ashmus, ${ }^{254}$ the Court gave a confusing partial explanation of the proper sequence in which sovereign immunity and merits should be considered, finding that Article III "case or controversy" questions such as standing should be decided before sovereign immunity issues. Explaining this order of proceeding, the Court observed in a footnote that "[w]hile the Eleventh Amendment is jurisdictional in the sense that it is a limitation on the federal court's judicial power, and therefore can be raised at any stage of the proceedings, we have recognized that it is not coextensive with the limitations on judicial power in Article III."255

Yet despite this suggestion that sovereign immunity does not fall in the same category as core Article III issues-and should be decided subsequent to them-Calderon left unresolved the question of whether it is permissible to decide merits questions before sovereign immunity ones. Moreover, in Vermont Agency of Natural Resources v. U.S. ex rel. Stevens, the Court soon complicated matters, suggesting in dicta that it was proper to treat sovereign immunity issues before merits ones, since "[q]uestions of jurisdiction, of course, should be given priority." 256 As a result of these

250. 523 U.S. at 94 .

251. Id.

252. Id. at 95 .

253. For a discussion of lower courts' treatment of this issue before and after Steel Co., see Scott C. Idleman, The Demise of Hypothetical Jurisdiction in the Federal Courts, 52 VAND. L. REv. 235, 327-28 (1999).

254. 523 U.S. 740,742 (1998).

255. Id.

256. 529 U.S. $765,778-80$ (2000). To illustrate the almost endless confusion surrounding this issue, the Court in Vermont Agency did hold that a court could consider whether a statutory cause of action exists before turning to Eleventh Amendment issues. Id. at 779. At least one court has thus cited 
cryptic and conflicting pronouncements, many courts have continued to treat sovereign immunity in more or less the same manner as jurisdictional restrictions for the purpose of ordering issues. A few weeks after the Court's decision in Calderon, for example, the Eleventh Circuit held with little explanation that Steel $C o$. required it to consider sovereign immunity issues, as "essentially" challenging subject matter jurisdiction, before merits issues. ${ }^{257}$ Ignoring the Calderon footnote, the court instead cited Seminole Tribe's statement that "[t]he Eleventh Amendment restricts the judicial power under Article III."258

Other circuits have, however, considered the matter at more length and reached the opposite result. In Parella $v$. Retirement Board of the Rhode Island Employees' Retirement System, ${ }^{259}$ the First Circuit not only concluded that post-merits consideration of sovereign immunity issues is permissible under Steel Co., but found that such delayed consideration can promote judicial efficiency and fairness to litigants. The First Circuit reasoned that in cases that present "an easy merits issue (favoring the defendant) and a difficult Eleventh Amendment question,, 260 reaching the merits first has two positive effects: it conserves judicial resources and it "avoids forcing defendants to squander their resources on Eleventh Amendment questions." In addition, the First Circuit noted that because most Eleventh Amendment issues are fact-intensive and often bound up in merits issues ${ }^{261}$ the court that inflexibly decided such questions first would often, ironically, be compelled to "consider the merits of the plaintiffs' claims in great detail... in order to answer the supposedly prior question of Eleventh Amendment immunity." ${ }^{262}$ In such a case, the court noted, a state defendant who wanted to avert an unwelcome precedent on the Eleventh Amendment issue would have to litigate aggressively even if the issue ultimately proved unnecessary to the court's decision. Moreover, courts hearing such cases would be obliged to "begin their opinions with the equivalent of 'obligatory dicta." "263

This reasoning does not, of course, apply in every case. Some sovereign immunity issues are easily resolved, and early consideration of them

\footnotetext{
this case in support of its decision to postpone consideration of sovereign immunity questions. See Broselow v. Fisher, 319 F.3d 605, 607 (3d Cir. 2003).

257. Seaborn v. Fla. Dept. of Corr., 143 F.3d 1405, 1407 (11th Cir. 1998) (citing Seminole Tribe v. Florida, 517 U.S. 44, 72-73(1996)).

258. Id.

259. 173 F.3d 46 (1st Cir. 1999).

260. Id. at 56 .

261. Id. As the court observed, Ex parte Young retroactivity issues are particularly likely to be bound up with the merits; many other issues, such as whether a particular state agency is an arm of the state, may also be fact-intensive.

262. Id. at 56 n.6.

263. Id. at 56-57.
} 
may help a court to dispose of a case speedily and efficiently. ${ }^{264}$ Moreover, when sovereign immunity arguments are easily decided, prompt consideration of them is necessary to ensure that states receive the protection from extensive litigation that the doctrine is designed to afford. Nevertheless, when the defendant is likely to prevail on the merits, there are good arguments for allowing courts to order issues at their discretion rather than compelling them to hear sovereign immunity arguments first.

A recent flurry of litigation bears out the Parella court's point that tackling complicated sovereign immunity issues can unnecessarily prolong litigation. Over the past few years, courts in nearly every circuit have faced a spate of claims by Medicaid recipients asserting rights to a share of the Master Settlement Agreement (MSA) and other settlements negotiated between tobacco companies and states. ${ }^{265}$ Because the MSA funds are to be paid on an ongoing basis and were ostensibly designed to alleviate states' future financial burdens in providing medical care to residents suffering from tobacco-related illnesses, the claims presented complex issues of Young retroactivity. Courts were obliged to consider whether state officials could be subject to a Young injunction requiring them to transfer some of the future funds to the plaintiffs, or conversely whether the plaintiffs' claims were essentially assertions of a right to money damages for the state's past conduct, prohibited under Young.

The dozens of district and circuit courts to consider the MSA claims divided on this issue. ${ }^{266}$ They also divided on the Steel Co. question described above: whether they were obliged to resolve the Young issues before reaching the merits of the case. ${ }^{267}$ Some courts in addition attempted to decide sovereign immunity issues on other grounds, such as whether the state, by entering into the settlement, had waived its sovereign immunity. ${ }^{268}$ Nevertheless, this multiplicity of disagreements concealed a fundamental convergence of opinion. Those courts that ultimately reached the merits issues, either because their circuit allowed postponement of sovereign

264. For an argument to this effect, see Jonathan R. Siegel, Waivers of State Sovereign Immunity and the Ideology of the Eleventh Amendment, 52 DUKE L.J. 1167, 1231 (2003).

265. See Broselow v. Fisher, 319 F.3d 605 (3d Cir. 2003); Barton v. Summers, 293 F.3d 944 (6th Cir. 2002); Cardenas v. Anzai, 311 F.3d 929 (9th Cir. 2002); Greenless v. Almond, 277 F.3d 601 (lst Cir. 2002); Strawser v. Atkins, 290 F.3d 720 (4th Cir. 2002); Harris v. Owens, 264 F.3d 1282 (10th Cir. 2001); McClendon v. Ga. Dept. of Cmty. Health, 261 F.3d 1252 (11th Cir. 2001); Tyler v. Douglas, 280 F.3d 116 (2d Cir. 2001); Watson v. Texas, 261 F.3d 436 (5th Cir. 2001); Floyd v. Thompson, 227 F.3d 1029 (7th Cir. 2000).

266. Compare Barton, 293 F.3d at $949-50$ (holding that because state had a present financial interest in the funds, the suit was barred by state sovereign immunity) with Cardenas, 311 F.3d at 937 38 (finding that suit could proceed because plaintiffs did not seek recovery of past funds but rather distribution of "overage" on an ongoing basis).

267. The First, Second, Third, Fourth, Seventh, and Eleventh circuits concluded that they could reach the merits first. See Broselaw, 319 F.3d at 607; Greenless, 277 F.3d at 607-08; Strawser, 290 F.3d at 730; Tyler, 280 F.3d at 121; McClendon, 261 F.3d at 1259; Floyd, 227 F.3d at 1035.

268. See Watson, 261 F.3d at 442. 
immunity questions or because they found that the Young exception did in fact apply, concluded without exception that the plaintiffs' claims could be easily dismissed on the merits. ${ }^{269}$

The MSA litigation, with its national reach and the huge sums of money at stake, ${ }^{270}$ illustrates the potential wastefulness of an approach that requires state sovereign immunity claims to be litigated before issues on the merits. Complicated sovereign immunity questions had to be litigated and appealed in district after district, circuit after circuit, even though all indications were that the underlying issues could have been quickly disposed of. The fact that certain circuits prohibited courts from hearing the merits first not only cost money and resources, but prolonged uncertainty about the status of millions of dollars in state funds. Far from keeping states out of litigation, applying the Steel Co. approach to sovereign immunity ensured that they remained enmeshed in it.

When courts conclude that state sovereign immunity is jurisdictional, they are unable to take such litigation costs into account. Federal question jurisdiction is, after all, a question of the extent of the court's power, not an attempt to balance costs and benefits. Yet where sovereign immunity is concerned, the strict approach that jurisdiction demands is incongruous, both in light of the doctrine's long-unsettled status and the fact that the Supreme Court itself has been willing to balance competing interests in deciding sovereign immunity cases. ${ }^{271}$ While jurisdictional absolutism may serve important ends when it comes to enforcing Article III limits, these justifications are not easily translated into the sovereign immunity context.

\section{B. Absence of Guidance: The Troublesome Sua Sponte Question}

If the jurisdictional notion of state sovereign immunity has the potential to impose substantial costs on courts, it may also fail to provide them with adequate guidance. Because Article III considerations by their very nature admit no exceptions, a jurisdictional conception fails to help courts understand how to exercise the discretion given to them, and how to engage in line-drawing where it is necessary. This problem is exacerbated by the absence of external textual sources for or historical consensus about current state sovereign immunity doctrine, which compels courts to rely nearly exclusively on the Supreme Court's characterizations in order to understand the doctrine's nature and scope.

This problem has recently surfaced in the lower court confusion about the court's obligation to raise sovereign immunity issues. Under current

269. See Broselaw, 319 F. 3d at 607-08 (reviewing, and joining, the consensus reached by other circuits).

270. Hawaii's tobacco settlement alone amounted to 1.38 billion dollars (payable over 25 years). See Cardenas v. Anzai, 128 F. Supp. 2d 704 (D. Haw. 2001).

271. See discussion supra Part I1.A. 
Supreme Court precedent, lower courts have discretion to raise or not to raise sovereign immunity issues sua sponte, a power that-in part because of the murkiness of the Supreme Court's pronouncements-is nearly unlimited. By contrast, courts must raise core Article III issues sua sponte. The jurisdictional characterization therefore gives courts no guidance whatsoever in how to exercise meaningful discretion with regard to what is frequently an important issue-and one that has invited strategic behavior by states.

The question of a court's obligation to raise a sovereign immunity issue sua sponte has been extraordinarily difficult for the lower courts. Even before Seminole Tribe, the Supreme Court's pronouncements on the subject pointed in different directions. In Patsy $v$. Florida Board of Regents, the Court held that the Eleventh Amendment was not "jurisdictional in the sense that it must be raised and decided by this Court on its own motion."272 Two years later, however, the Court in Pennhurst stated that a federal court "must examine each claim in a case to see if the court's jurisdiction over the claim is barred by the Eleventh Amendment."273 While some circuits continued to read Patsy as allowing them the choice whether or not to raise sovereign immunity sua sponte, others took Pennhurst to overrule or qualify Patsy's holding on this issue, and held that courts were required to raise an Eleventh Amendment issue if they noticed it. ${ }^{274}$ When the Court in Seminole Tribe reaffirmed that the Eleventh Amendment "restricts the judicial power under Article III,"275 many courts saw the decision as an affirmation of the Pennhurst view, requiring courts to raise the issue, like any subject matter jurisdiction question, on their own. ${ }^{276}$

In Wisconsin Department of Corrections $v$. Schacht, ${ }^{277}$ however, the Court rejected this view in a unanimous opinion, stating that "the Eleventh Amendment ... does not automatically destroy original jurisdiction" and "[u]nless the State raises the matter, a court can ignore it." Schacht appears to give federal courts wide discretion in dealing with sovereign immunity

\footnotetext{
272. 457 U.S. $496,515(1982)$.

273. 465 U.S. 89,121 (1984).

274. See, e.g., V-1 Oil v. Utah State Dep't of Pub. Safety, 131 F.3d 1415, 1419-20 (10th Cir. 1997) (addressing sovereign immunity issue sua sponte notwithstanding the fact that the state did not raise it at either trial or appellate level); Maseheroni v. Bd. of Regents, 28 F.3d. 1554, 1557-59 (10th Cir. 1994) (discussing Pennhurst's effect on Patsy and noting circuit split on the issue); Atl. Healthcare Benefits Trust v. Googins, 2 F.3d 13 (2d Cir. 1993) (court must raise issue sua sponte because it affects subject matter jurisdiction). But see Benning v. Bd. of Regents of Regency Univs., 828 F.2d 775, 777 n.2 (7th Cir. 1991) ("We are not obliged to reach the Eleventh Amendment issue because the Eleventh Amendment doctrine of sovereign immunity, though often characterized as jurisdietional, does not function as a true jurisdictional bar.").

275. Seminole Tribe v. Florida, 517 U.S. 44, $72-73$ (1996).

276. See, e.g., Nelson v. Geringer, 295 F.3d 1082, 1098 n.16 (10th Cir. 2002); Wilson-Jones v. Caviness, 99 F.3d 203, 206 (6th Cir. 1996).

277. 524 U.S. 381,389 (1998).
} 
questions $^{278}$; most courts have interpreted it as permitting them to raise the sovereign immunity issue sua sponte if they choose. ${ }^{279}$

Nevertheless, lower courts continue to express uncertainty about the implications of Schacht, particularly in light of subsequent Supreme Court cases that have reverted to subject matter jurisdiction language in talking about sovereign immunity. In Regents of the University of Minnesota $v$. Raygor, ${ }^{280}$ the district court found that Schacht had not resolved the issue of whether a federal court has jurisdiction over a claim against a state entity up until the point a sovereign immunity claim is successfully asserted. The court noted that reliance on Schacht's statement that the Eleventh Amendment "does not automatically destroy original jurisdiction" "misplaced."282 Schacht's holding, the court observed, was arguably confined to the situation in which a claim barred by sovereign immunity was joined with other non-barred federal claims that established an independent basis for jurisdiction. ${ }^{283}$ Additionally, the court noted that the Supreme Court had subsequently undercut Schacht's dicta ${ }^{284}$ when it reverted to the language of subject matter jurisdiction in Kimel v. Florida Board of Regents-in which the Supreme Court found it "clear" that "the Constitution does not provide for federal jurisdiction over suits against nonconsenting states." 285

This welter of competing pronouncements has left lower courts understandably confused. Yet even apart from questions about the actual extent of the discretion Schacht gives courts to raise or not raise Eleventh Amendment issues, the Supreme Court has given lower courts virtually no guidance in how to exercise whatever discretion they do possess. ${ }^{286}$ Schacht allows federal courts to "ignore" such issues, but does little to

278. See Michelle Lawner, Why Federal Courts Should Be Required to Consider State Sovereign Immunity Sua Sponte, 66 U. CHI. L. REv. 1261 (1999).

279. See, e.g., Higgins v. Mississippi, 217 F.3d 951, 953 (7th Cir. 2000) (noting that the Schacht court "said only that the fcderal court could ignore the immunity in such a case, not that it must ignore it"); see also Parella, 173 F.3d 46, 55 (1st Cir. 1998).

280. 620 N.W. 2d 680, 684 nn.2-3 (Minn. 2001); F. Ryan Keith, Note, Must Courts Raise the Eleventh Amendment Sua Sponte? The Jurisdictional Difficulty of State Sovereign Immunity, 56 WASH. \& LEE L. REv. 1037 (1999).

281. 524 U.S. at 389.

282. 620 N.W. 2 d at 684 n.3.

283. Id.

284. Id. at 684 n.2; see also Watkins v. Cal. Dep't of Corr., 100 F. Supp. 2d 1227, 1231 \& n.5 (C.D. Cal. 2000) (noting that subsequent decisions such as Alden v. Maine expanding the range of sovereign immunity had cast doubt on some elements of Schacht).

285. 528 U.S. $62,73(2000)$

286. See, e.g., Higgins v. Mississippi, 217 F.3d 951, 953-54 (7th Cir. 2000) (noting existence of questions about when a court should exercise its discretion sua sponte, but dcclining to consider the issue). But see Detroit Edison Co. v. Mich. Dep't of Envtl. Quality, 29 F. Supp. 2d 786, 791 (E.D. Mich. 1998) (considering allegations of state "gamesmanship" in deciding whether to raise the Eleventh Amendment issue sua sponte, thus perhaps responding to concerns raiscd in Justice Kennedy's Schacht concurrence). 
explain why courts might wish to raise them. ${ }^{287}$ Thus, courts have also expressed uncertainty about which factors should weigh in the determination to raise or to ignore Eleventh Amendment issues. ${ }^{288}$

While the power and obligation of federal courts to raise the sovereign immunity issues on their own motion is thus widely disputed, the ability of states to raise the issue on appeal is, by contrast, clearly established. The Supreme Court has allowed state litigants to raise sovereign immunity defenses at any stage of litigation, no matter how late ${ }^{289}$ and no matter what unfairness to plaintiffs may result. The interaction of this rule with the doctrine that a court may, but need not, raise a sovereign immunity issue sua sponte has led to curious results. Concurring in Schacht, Justice Kennedy noted that the rule allowing states to raise sovereign immunity issues not presented at trial allows potentially unfair consequences for plaintiffs and encourages manipulative behavior by states:

In permitting the belated assertion of the Eleventh Amendment bar, we allow States to proceed to judgment without facing any real risk of adverse consequences. Should the State prevail, the plaintiff would be bound by principles of res judicata. If the State were to lose, however, it could avoid the entire judgment simply by asserting its immunity on appeal. ${ }^{290}$

The possibility of deliberately belated sovereign immunity assertions has led some courts to speculate about whether it might be necessary for the court to raise Eleventh Amendment issues in order to protect plaintiffs. At least one court has weighed the possibility of bad faith by states in deciding whether to raise the sovereign immunity issue. ${ }^{291}$ One commentator has suggested that, in light of the potential for such strategic behavior by states, courts should always consider any possible Eleventh Amendment issues at the outset of litigation. ${ }^{292}$ Yet while protecting plaintiffs in certain cases, such a practice could have harsh overall consequences for them. For example, suppose a county-based agency withheld sovereign immunity issues because it knew that it was unlikely to be considered a division of the state for Eleventh Amendment purposes. A court's sua sponte introduction of the issue would force a plaintiff to expend needless resources in establishing that the agency was subject to suit.

287. Schacht, 524 U.S. at 389

288. See Higgins, 217 F.3d at 953-54.

289. Some Supreme Court authority indicates that raising the defense for the first time before the Supreme Court, for example, is not too late. See Ford Motor Co. v. Dep't of Treasury, 323 U.S. 459, 467 (1945), overruled on other grounds by Lapides v. Bd. of Regents, 535 U.S. 613 (2002).

290. Schacht, 524 U.S. at 394.

291. See Detroit Edison Co., 29 F. Supp. at 791. Interestingly, the court ultimately deeided not to raise the Eleventh Amendment sua sponte.

292. See Lawner, supra note 278 , at 1261. 
More fundamentally, it is unclear whose interests should matter in this determination. Should courts simply weigh the balance of harm to each litigant? Is an interest in conserving judicial resources a fair consideration? Should the special factors that have prevailed in the sovereign immunity context more generally - such as the need to protect states or to vindicate federal law-receive particular consideration? Should courts speculate about whether the state appears to be acting in good faith? Such considerations may arise in any issue courts are permitted to determine sua sponte, but they are particularly acute where sovereign immunity is concerned because the doctrine's unsettled jurisdictional status sends mixed signals to courts about how they should regard the issue.

Historically, the issue of whether to raise sovereign immunity sua sponte has been tied up with jurisdictional issues. Many courts have been in the practice of simply raising the issue on their own because they consider it a question of their subject matter jurisdiction. Under the ordering principle of Steel Co., however, the jurisdictional view is simply inconsistent with Schacht's pronouncements that courts may ignore sovereign immunity issues if they wish. The disparity between the two cases has led many courts, in an "abundance of caution," "293 to adhere to the jurisdictional view and raise Eleventh Amendment issues whenever they arise.

By leading courts to introduce Eleventh Amendment issues needlessly, this all-consuming focus on jurisdictional issues has undoubtedly cost resources and created unpleasant surprises for plaintiffs. Perhaps even more importantly, it has misdirected the lower courts' inquiry toward the jurisdictional question and thus inhibited them from developing a satisfying body of doctrine to grapple with a difficult question.

\section{Oddities and Distractions: The Jurisdictional View as Generator of Judicial Error}

Finally, it is worth observing the frequency with which the jurisdictional view has misled lower courts about the Supreme Court's understanding of the doctrine, leading to decisions that have been speedily and unanimously reversed by a Supreme Court that is, in general, famously fractured on sovereign immunity issues. ${ }^{294}$ Such cases, if nothing else, suggest that the jurisdictional view is sending the wrong signals-and that for courts to take the jurisdictional view too seriously leads them to results that are dramatically at odds with the way the Court conceives of sovereign

293. Nelson v. Geringer, 295 F.3d 1082, 1098 n.15 (10th Cir. 2002).

294. Among the unanimous opinions from the past several years vacating or reversing lower court decisions on sovereign immunity issues are: Frew v. Hawkins, 124 S.Ct. 899 (2004), Lapides v. Bd. of Regents of Univ. Syst. of Ga., 535 U.S. 613 (2002), Verizon Md., Inc. v. Pub. Serv. Comm'n of Md., 535 U.S. 635 (2002); Calderon v. Ashmus, 523 U.S. 740 (1998); Schacht, 524 U.S. 381 (1998). 
immunity doctrine. Two recent cases illustrates how easily lower courts can become confused.

\section{Schacht v. Wisconsin Department of Corrections}

In Schacht, the Court unanimously reversed the Seventh Circuit's holding that the presence of sovereign immunity issues in certain claims in a case destroyed removal jurisdiction over related claims. In Schacht, a prison guard who had been fired brought various civil rights claims against state officials in their individual and personal capacities. ${ }^{295}$ The defendants removed the case to federal court, where they raised the defense that claims against the defendants in their official capacities were subject to an Eleventh Amendment bar. ${ }^{296}$ The district court granted the defendants' motion to dismiss on these claims and summary judgment on the remaining claims.

On appeal, the Seventh Circuit concluded that, because the federal court lacked jurisdiction over the case, removal was improper. The court reasoned that, since some of Schacht's claims had been barred by the Eleventh Amendment, "the district court lacked jurisdiction over the case because sovereign immunity acted as a limit on the original subject matter jurisdiction of the courts with respect to the barred claims."297 The court distinguished this situation from one in which the removed case contains both federal and state-law claims, in which the court may decide state law claims even after the federal claims are dismissed. Successful assertions of sovereign immunity were different, the court argued, because "[c]laims barred by sovereign immunity stand on different footing than other claims that are not independently removable, because of the affirmative limitation on jurisdiction imposed by the sovereign immunity doctrines." 298

Unanimously reversing, the Supreme Court rejected the Seventh Circuit's implied analogy between state sovereign immunity and the absence of federal jurisdiction, cataloguing the ways in which state sovereign immunity functioned differently from jurisdictional deficiencies under Article III. In contrast to such deficiencies, the Court noted:

The Eleventh Amendment... does not automatically destroy original jurisdiction. Rather, the Eleventh Amendment grants the State a legal power to assert a sovereign immunity defense should it choose to do so. The State can waive the defense .... Nor need a court raise the defect on its own. Unless the State raises the matter, a court can ignore it. ${ }^{299}$

\footnotetext{
295. Schacht, 524 U.S. at 383.

296. Id. at 384.

297. Schacht v. Wisconsin Dep't. of Corr., 116 F.3d 1151, 1152 (7th Cir. 1997).

298. Id.

299. Schacht, 524 U.S. at 389.
} 
Lower courts were incorrect, therefore, in "look[ing] to removal based upon 'diversity jurisdiction' . . for analogical authority."300 Although Justice Breyer's opinion noted that the jurisdictional status of state sovereign immunity was "a question we have not decided," the Court's reasoning suggests that it should not be simply presumed. ${ }^{301}$

The Court's opinion thus indicates that the Seventh Circuit's error was, in some sense, taking the Court's pronouncements of state sovereign immunity's jurisdictional status too literally. The Seventh Circuit, in reaching its holding, was apparently attempting to reason out the implications that would follow were sovereign immunity to be treated in the same manner as other jurisdictional judgments federal courts must make. In rejecting the Seventh Circuit's holding, however, the Court started from the premise that state sovereign immunity does not resemble other forms of subject matter jurisdiction sufficiently to permit such analogies. Notably, all nine members of the Court were willing to endorse this holding. ${ }^{302}$

\section{Frew v. Hawkins}

In early 2004, the Supreme Court in Frew v. Hawkins unanimously rejected a similarly literalist view of the jurisdictional nature of state sovereign immunity doctrine. ${ }^{303}$ Prior to Frew, the Fifth Circuit had found over the course of several cases that the limits Pennhurst places on Young suits also restrict federal court jurisdiction to enforce consent decrees ${ }^{304}$ into which a state has entered voluntarily. Because Pennhurst forbids Young injunctions that direct state officials to follow state law, the Fifth Circuit concluded that federal courts similarly lack jurisdiction to enforce consent decrees that are not clearly grounded in federal law.

The issue in Frew involved a difficult "intersection" between two areas of federal court doctrine: on the one hand, federal courts' broad authority to approve consent decrees under Local Number 93, International Association of Firefighters $v$. City of Cleveland ${ }^{305}$ and, on the other, Pennhurst's Eleventh Amendment-based prohibition of Young injunctions not grounded in federal law. ${ }^{306}$ In Lelsz v. Kavanagh, the Fifth Circuit, reasoning that the jurisdictional prohibition of the Eleventh Amendment was paramount, decided this conflict in favor of Pennhurst. ${ }^{307}$ The court

300. Id. at 388 .

301. See id. at 391 .

302. Justice Kennedy wrote a concurrence that expanded on the Court's opinion but fully affirmed its holding. Id. at 393.

303. 124 S. Ct. 899 (2004).

304. A consent decree is defined as a "court decree that all parties agree to"; it possesses elements of both a court order and a contract. BLACK's LAW DiCTIONARY 419 (7th ed. 1999).

305. 478 U.S. 501, 525 (1986) (recognizing that federal courts have wide latitude to issue consent decrees and that "a federal court is not neeessarily barred from entering a consent decree merely because the decree provides broader relief than the court could have awarded after a trial").

306. See Frew, 124 S. Ct. at 903. 
paramount, decided this conflict in favor of Pennhurst. ${ }^{307}$ The court thus invalidated a federal court's order implementing a prior consent decree in a $\S 1983$ action, finding that provisions in the order appeared to be based on state rather than federal law. ${ }^{308}$ The Fifth Circuit concluded that even though the consent decree at issue in the case had been validly entered under Firefighters, a court order enforcing it was invalid under Pennhurst. ${ }^{309}$ Drawing a comparison to Pennhurst, the Fifth Circuit concluded that "no federal right [is] vindicated" by a "remedy unfounded in federal law [that] intrudes into the governance of matters otherwise presided over by the states."

Despite the skepticism of some of its own judges ${ }^{310}$ and criticism from commentators, ${ }^{311}$ the Fifth Circuit steadily expanded this Pennhurstflavored view of consent decrees, holding that federal court orders enforcing a consent decree against a state were valid only insofar as they directly addressed a violation of federal law. ${ }^{312}$ This process of expansion culminated in Frazar v. Gilbert, in which the Fifth Circuit invalidated a consent decree between parents of children receiving Medicaid and Texas state officials. ${ }^{313}$ The court held that orders enforcing the consent decree were beyond the district court's jurisdiction unless "an alleged violation of the consent decree would constitute, in the absence of the decree, a [federal] statutory violation... remediable under $\S 1983 . " 314$ Thus, the district court's detailed order implementing the decree was invalid.

The Supreme Court reversed unanimously in Frew v. Hawkins, notably choosing to rest its result on the enforceability of the consent decree itself rather than the potentially more straightforward ground that the state had waived its sovereign immunity by entering into the decree. ${ }^{315}$ In a terse and unsatisfying opinion, the Court acknowledged the Fifth Circuit's

\section{815 F.2d 1034 (5th Cir. 1987).}

308. Id. at 1035 .

309. Id. at 1252. The Fifth Circuit later suggested that Firefighters simply does not apply if the court "lacks jurisdiction as a result of the Eleventh Amendment." Frazar v. Gilbert, 300 F.3d. 530, 543 (5th Cir. 2002) (noting that "Firefighters is a consent decree case but is not an Eleventh Amendment case, and does not therefore address the deference federal courts must show for the Eleventh Amendment when called upon to enjoin state officials under Ex parte Young"). From a plaintiff's point of view, of course, the distinction between a court's ability to enter a consent decrees versus its ability to enforce it is of little significance, since court approval of an unenforceable consent decree is of little benefit. See Jeremy Wright, Note, Federal Authority to Enforce Consent Decrees Against State Officials, 6 TEX. F. ON C.L. \& C.R. 401 (2002).

310. See Lelsz, 815 F.2d at 1035.

311. See Wright, supra note 309.

312. See Saahir v. Estelle, 47 F.3d 758 (5th Cir. 1995); see also Wright, supra note 309, at 416-17 (noting that subsequent Fifth Circuit cases, such as Ibarra v. Texas Employment Commission, 823 F.2d 873 (5th Cir. 1987), havc given courts some scope in applying Lelsz, but that the net effect has been to create increased uncertainty about the enforceability of consent decrees against states).

313. Frazar v. Gilbert, 300 F.3d 530 (5th Cir. 2002).

314. Id. at 537.

315. See Frew, 124 S. Ct. at 903. 
reliance on Pennhurst, but found that the order in Frew was distinguishable because it was entered "to implement a federal statute." This was a relevant distinction, the Court found, notwithstanding the fact that the decree implemented the statute "in a highly detailed way, requiring the state officials to take some steps that the statute does not specifically require." 316

In support of its argument, the Court relied on a case from a different Ex parte Young context: Hutto v. Finney, in which the Court had held that an award of attorney's fees designed to "encourage state compliance with an existing court order" did not violate Edelman's ban on monetary relief. ${ }^{317}$ Hutto, of course, concerned a fundamentally different aspect of Young doctrine-that is, the scope of the remedies that could be permissible in a Young lawsuit, not a federal court's power to order a state official to perform an action not mandated by federal law. While acknowledging this distinction, ${ }^{318}$ the Court emphasized the common thread between the two cases: a federal court's need to enforce its authority through court orders. As the Court proclaimed, "Federal courts are not reduced to approving consent decrees and hoping for compliance.",319

On the one hand, the Court's reasoning is admirable and understandable. To deny a court authority to enforce a valid consent decree it has previously entered, or even to restrict substantially its ability to fashion such orders, would vitiate judicial authority to an inconceivable degree. Yet however valid this concern, it does not directly address the Fifth Circuit's arguments. While Lelsz and Frazar may have been poor policy, they are a not wholly irrational response to the view of sovereign immunity as an absolute jurisdictional prohibition that must be approached with caution. If, as Pennhurst announces, the prohibition on Young injunctions not grounded in federal law is jurisdictional, ${ }^{320}$ it is difficult to see why federal courts should be able to expand their jurisdiction simply because a consent decree exists. This concern might be particularly acute in light of the broad power Firefighters gives federal courts to issue enforcement orders that go well beyond the literal terms of the consent decree. The power of a federal court to enforce a consent decree is potentially vast, and in the absence of a clear basis for its jurisdiction, the specter of a court reaching out to enforce self-fashioned orders against state officials-mandating actions that would otherwise lie outside its jurisdiction-is troubling if one takes the

\footnotetext{
316. Id. at 904 .

317. Id. at 905 (citing Hutto v. Finney, 437 U.S. 678, 685 (1978)).

318. Id. (noting that Finney "involved the scope of remedies for violation of a prior order rather than the antecedent question of whether remedies are permitted in the first instance").

319. Id.

320. Because it found that the order at issue did have an underlying federal basis, the Court in Frew did not resolve the issue of whether it is permissible for federal court orders to mandate actions required under statc but not federal law, although Frew's expansive language suggests that federal courts will be given a great deal of latitude. If consent decrees can in fact order actions derived from specific state law provisions, the line between Frew and Pennhurst seems awfully thin.
} 
jurisdictional view seriously. That the Supreme Court was not bothered by this prospect suggests that it does not.

The Court might have easily sidestepped this issue by holding that the state, in entering into the consent decree, had waived its sovereign immunity. It could then have distinguished Pennhurst on the basis that the state in Frew had consented to federal jurisdiction where, in Pennhurst, it had not. The Court, however, specifically declined to rest its holding on the waiver issue. ${ }^{321}$ The only way to make sense of the Court's opinion, then, appears to be that lower courts are not intended to take Pennhurst's jurisdictional pronouncements literally, at least not outside a very limited context.

Schacht and Frew illustrate the difficulty lower courts have in logically reconciling the Supreme Court's competing pronouncements. By failing to explicitly repudiate the jurisdictional view, while at the same time emphasizing the importance of observing Article III boundaries, the Supreme Court has tacitly encouraged lower courts to exercise excessive zeal in ensuring that they do not overstep the limits of their power. Schacht and Frew, however, illustrate that this tendency often leads lower courts to embrace results that the Supreme Court considers erroneous. This is troublesome not merely because it wastes judicial resources, ${ }^{322}$ but because it illustrates the haphazardness and inconsistency of Supreme Court doctrine. Until the Court clarifies the jurisdictional issue, however, lower courts' efforts to transfer the formalism appropriate to Article III concerns to the sovereign immunity context will likely lead to more lower court misunderstanding and more unanimous reversals.

IV.

\section{Possible Alternatives}

As the preceding section has argued, the Supreme Court's conflicting pronouncements about sovereign immunity's jurisdictional status-and the doctrinal tangles the Article III view of sovereign immunity has generated-have created widespread confusion and wasted judicial resources. For the Supreme Court to hold squarely that state sovereign immunity is not jurisdictional would help to conserve judicial energies and bring greater clarity to an often contested doctrine. Moreover, a nonjurisdictional view of sovereign immunity would not entail a radical revision of the Court's

321. Frew, $124 \mathrm{~S} . \mathrm{Ct}$. at 903.

322. Nevertheless, on that score, it is worth noting that the underlying case in Frew was a massive class action potentially affecting 1.5 million Texas children. See Frazar v. Gilbert, 300 F.3d 530, 534 (2002). 
precedents. It would simply require the Court to expand upon suggestions it has already made in some cases and deemphasize language in others. ${ }^{323}$

This is not to say, however, that all of the competing sovereign immunity characterizations the Court has developed in the past are equally suitable for such a project. Some seem manifestly inappropriate to anchor a comprehensive theory of the doctrine. This Part explores several of these characterizations, rejecting suggestions that sovereign immunity should be considered a right, a structural constitutional principle, or a form of personal jurisdiction, and ultimately arguing that sovereign immunity can most properly be characterized as a defense.

The view of sovereign immunity as a right is the easiest to reject. Logically, the analogy is strained at best. As one commentator has noted, the view appears to represent a move toward anthropomorphizing states similar to the development of corporate personhood in the late nineteenth century. ${ }^{324}$ The analogy is just as troublesome, if not more so, in the sovereign immunity context. States, after all, are not human, and even if state "dignity" is implicated in sovereign immunity questions, it is clearly of a different kind than the dignity involved in protecting, say, the rights of

323. This suggestion is not as implausible as it may initially appear. Although the fact has been obscurcd by the stark 5-4 divide between justices who view sovereign immunity as a broad constitutional principle and those who sce it as a common law doetrine subject to congressional abrogation, there appears to exist a majority, composed of the four frequent disscnters in sovereign immunity cases plus Justice Kennedy, willing to hold that sovereign immunity is not a question of subject matter jurisdiction.

For the four dissenters (and many eommentators), sovereign immunity is simply a common law doctrine that has never bcen incorporated into the Constitution. Dissenting in Seminole Tribe, for cxample, Justice Souter, while acknowledging that sovereign immunity was recognized in the colonics as a matter of common law, argued that it was always subject to legislative amendment and was never "elevated to constitutional status." Seminole Tribe, 517 U.S. 44, 138 \& n.34 (1996). "[O1ther forms of common law immunities, such as the immunity enjoyed under certain circumstances by public officials," Justice Souter noted, have been recognized by the courts, but are not of constitutional status and can be modified by Congress; because sovereign immunity as the Court has applied it is not textually mandated, it bears no obvious differences from such othcr official protections. See $i d$. This view, whatever its other implications, at the very least clearly rejects the idea that sovereign immunity is a jurisdictional doctrine embodied in Article 1II. In other contexts, the dissenters have explicitly maintained this view; Breyer, for example, writing for the majority in Schacht, sees sovereign immunity as a waivable privilege. Wis. Dept. of Corr. v. Schacht, 524 U.S. 381, 389 (1998). Other dissenting justices appear to share Souter's general views. Justices Breyer and Ginsburg joined Soutcr's Seminole Tribe dissent; Justice Stevens echoed much of his reasoning in a separate dissent. See Seminole Tribe, 517 U.S. at 99-100 (Souter, J., dissenting) and 78-80 (Stevens, J., dissenting).

Moreover, it is possible that other justices might be receptive as well. Justice Scalia, for example, has described state sovereign immunity in terms that suggest he believes it to be distinct from ordinary Article III considerations. See ITSI TV Prods., Inc. v. Agric. Assoc., 3 F.3d 1289, 1291 (9th Cir. 1993) (citing Blatchford v. Native Village of Noatak, 501 U.S. 775 (1991)) (interpreting Justice Scalia's Blatchford distinction between jurisdiction over a claim and defenses to a claim as indicating a nonjurisdictional view of sovereign immunity). In addition, as diseussed, all nine Justices have joined opinions rejecting extreme lower court views on the jurisdictional question. See supra note 294. It is possible, therefore, that a redefinition of sovereign immunity might command fairly broad and ideologically diverse support on the Supreme Court.

324. See Sherry, supra note 217. 
criminal defendants. Vastly different considerations are involved in waiver of personal rights and waiver of state sovereign immunity. To take just one example, a state waiving state sovereign immunity is likely to receive comprehensive and sophisticated legal advice, something to which few human criminal defendants have comparable access.

This is not to say that the analogy of sovereign immunity as "right" might not be useful for conceptualizing some aspects of state sovereign immunity in certain carefully circumscribed contexts ${ }^{325}$ But a comprehensive "right" theory would result in many of the same problems as the Article III jurisdictional view. It is imprecise on a doctrinal level, comes with a great deal of baggage, and seems nearly as likely to confuse or mislead lower courts as the jurisdictional characterization.

A different argument might be made against a view of sovereign immunity as merely a structural constitutional principle, a perspective that cases like Alden $v$. Maine, which rely on an expansive state sovereignty theory, theoretically support. Such a view is likely too amorphous to be much of an improvement over the present situation in terms of providing guidance to lower courts. Particularly given the ideologically charged nature of the issue of state sovereign immunity in general, a structural view of sovereign immunity could quickly evolve into a fuzzy balancing test the application of which depends solely on an individual judge's substantive views on the desirability of strong state sovereign immunity protections.

A more interesting alternative conception of sovereign immunity is as a form of personal jurisdiction. While Kennedy's Schacht concurrence suggested that a personal jurisdiction view of sovereign immunity would harmonize better with current doctrine, his argument was grounded in fairness considerations, not textual or historical support. ${ }^{326}$ However, one commentator, Caleb Nelson, has argned that the personal jurisdiction conception of sovereign immunity and the Eleventh Amendment comports with the historical understanding as well ${ }^{327}$ In the eighteenth century, Nelson argues, the state's immunity was neither an affirmative right nor a restriction on subject matter jurisdiction, but simply the byproduct of an

325. For example, it might be reasonable to use the "right" analogy to justify a clear statement rule when a question of whether a state has waived its sovereign immunity is at issue. Even here, however, it is important to draw distinctions between waiver of sovereign immunity, which, if a right, is only a structural one, and personal constitutional rights. Thus, any inquiry into the validity or scope of a state's waiver should turn solely on the state's intentions as manifested in the language of the alleged waiver at issue. Other concerns that might be appropriate in assessing an individual's waiver of rights-such as that person's knowledge of her rights, disparities in bargaining power between the individual and the government, and so on-are simply inapplicable and inappropriate in the state sovereign immunity context.

326. Schacht, 524 U.S. at 393-98 (Kennedy, J., concurring) (arguing that the personal jurisdiction view would eliminate the unfair tactical advantage states gain by belatedly asserting Eleventh Amendment objections).

327. See Nelson, supra note 18 , at 1565 . 
understanding that the state could not be subjected to compulsory process. ${ }^{328}$ Nelson finds evidence for his theory in ratification discussions of the state's "amenability" to suit-a term, he argues, that was often used as a way of referring to personal jurisdiction. Nelson's theory also explains the "consent" exception to sovereign immunity, since a state may choose to appear in court voluntarily even if it cannot be served with process against its will. ${ }^{329}$

Nelson's personal jurisdiction view is, as a historical theory, remarkably well-argued and convincing. It also suggests a way in which current sovereign immunity doctrine could be made more theoretically coherent. A shift to a personal jurisdiction notion of sovereign immunity would make sense of some of the "jurisdictional bar" 330 language in previous cases, for example, in a way that is not dependent on a subject matter jurisdiction theory.

Ultimately, however, it is unclear what the effects would be of following the suggestion to reshape sovereign immunity doctrine in the terms of personal jurisdiction. Among other potential difficulties, it is hard to imagine importing the eighteenth century conception of personal jurisdiction as "amenability" to service of process into a post-Pennoyer world in which the limits of personal jurisdiction are defined only by statutory authority and the constraints of due process. Nelson himself concedes that the result of his theory might be simply to shift the terms of debate from the scope of sovereign immunity itself to the scope of Congress's power to subject states to compulsory process. ${ }^{331}$

Moreover, as Justice Kennedy acknowledged in Schacht, personal jurisdiction and sovereign immunity operate differently in practice. For example, courts must consider personal jurisdiction before reaching the merits of a case, while, as some courts have held and this Comment has urged, courts should not consider sovereign immunity first in all circumstances. ${ }^{332}$ Similarly, a party waives objections to personal jurisdiction by appearing to defend on the merits, while a state asserting sovereign

328. See id. at $1580-92$.

329. Id. at 1610 .

330. Of course, personal jurisdiction is not an Article 111 limitation. Nelson suggests, essentially, that sovereign immunity, while based on notions of personal jurisdiction, is in fact rooted in the "cases or controversies" language of Article III. However, he suggests that it may nonetheless be subject to broader ahrogation by Congress than current doctrine permits. See id. at 1639 (arguing that either a narrower or a broader understanding of Congress's abrogation powers would put the Court on "sounder footing" than its current muddled doctrine).

331. Id. at 1638-39.

332. Compare Zenith Radio Corp. v. Hazeltine Research, 1nc., 395 U.S. 100, 110 (1969) ("A court has no power to adjudicate a personal claim or obligation unless it has jurisdiction over the person of the defendant.") with Parella v. Ret. Bd. of Rhode lsland State Employees' Ret. Sys., 173 F.3d 46, 55 (1st Cir. 1999) ("Eleventh Amendment questions are excluded from the category of Article 111 issues that must be addressed before the merits."). 
immunity does not. ${ }^{333}$ For the Court to fully harmonize the doctrines would, then, require a substantial doctrinal shift.

Additionally, the personal jurisdiction view has the disadvantage of being a relatively recent theory. Whatever the view's historical support, Kennedy's Schacht concurrence appears to be the first explicit mention of the analogy in a Supreme Court case. Treating sovereign immunity as personal jurisdiction would therefore require a substantial reworking of previous cases, something the Supreme Court may be unwilling to undertake.

Perhaps the simplest and most logical choice the Court could make would be to find sovereign immunity to be-as the very term and many previous cases have suggested-a privilege, defense, or immunity. In other words, sovereign immunity would be conceived not as a limit on federal judicial power, but as an affirmative attribute possessed by states. Such a view would have the advantage of long usage, both in the Supreme Court itself and in lower courts deciding sovereign immunity issues. It would encompass most aspects of sovereign immunity doctrine, which resemble the ways in which the Court treats personal and national immunities in other contexts. Yet it would at the same time provide sufficient theoretical definition to aid courts in applying it.

The recent debate among the circuits about Steel Co.'s application to questions of state sovereign immunity illuminates the way in which the defense/immunity view makes sense of state sovereign immunity doctrine where the jurisdictional view does not. In United States v. Texas Tech University, the Fifth Circuit articulated one side of the debate, holding that Steel Co. applied to Eleventh Amendment issues because the amendment is fundamentally jurisdictional. ${ }^{334}$ As a result, the court concluded that " $[\mathrm{t}] \mathrm{o}$ rule on a merits question before, or in addition to, answering the omnipresent jurisdictional question would contravene the well-established principle that the federal courts may not issue advisory opinions."335

By contrast, in a subtle and persuasive opinion, Parella $v$. Retirement Board of the Rhode Island Employees' Retirement System, ${ }^{336}$ the First Circuit reasoned from the fundamental nature and purposes of sovereign immunity doctrine to conclude that sovereign immunity need not be considered before the merits. Reviewing existing Supreme Court cases that touched on the nature of sovereign immunity, the court concluded that the Eleventh Amendment "is just as much a grant of immunity (i.e., a type of defense) as it is a limitation on courts' jurisdiction." ${ }^{337}$ Regardless of whether sovereign immunity was or was not a limit on Article III, however,

333. See Fed. R. Civ. P. 12(h)(1).

334. 171 F. 3d 279, 285 (5th Cir. 1999) ("While often noted for preserving state sovereignty, the Amendment only accomplishes this end through jurisdictional limitation.").

335. Id. at 286 .

336. 173 F.3d at 55.

337. Id. 
the court concluded that the jurisdictional logic of Steel $\mathrm{Co}$. did not apply to sovereign immunity questions. As the court noted, Steel Co. was based on the underlying rationale that, where Article III jurisdiction has not been established, a court has no power to declare the law and "[is] only . . in a position to render an advisory opinion." ${ }^{338}$ In the sovereign immunity context, however, the court observed, the fact that a court need not raise an Eleventh Amendment issue sua sponte suggests that "the presence of an Eleventh Amendment issue does not threaten the court's underlying power to declare the law." 339 With this succinct statement of the difference between a jurisdictional restriction - an overall restraint on a court's powerand an immunity - which protects an individual litigant from having to put forth a defense-the First Circuit made a strong case that state sovereign immunity more closely resembles the latter.

The Court's recent emphasis on state sovereign immunity as an affirmative attribute that states possess also provides support for the Parella court's view. Decisions like Alden v. Maine are not concerned with the scope of federal judicial power established by the Constitution; they are instead focused on the privileges states retained when they entered the Union. Words like "privilege," "defense," and "immunity," have important differences in meaning and implication, ${ }^{340}$ but all of them capture the notion of sovereign immunity as something states possess, and that consequently can be waived by deliberate choice or outweighed by countervailing considerations (such as the Supremacy Clause in Ex parte Young suits).

As a mode of conceptualizing sovereign immunity, the defense/immunity view also has the advantage of offering a flexibility that the jurisdictional view does not. In Puerto Rico Aqueduct \& Sewer Authority $v$. Metcalf \& Eddy, Inc. ${ }^{341}$ for example, the Court noted that an immunity grounded in the Eleventh Amendment might be farther-reaching than an ordinary affirmative defense, such that, for example, an order denying it could be subject to immediate appeal. In Higgins v. Mississippi, ${ }^{342}$ the Seventh Circuit also discussed how a conceptualization of the Eleventh Amendment as an "immunity" would not necessarily require courts to consider it in the same light they do other affirmative defenses, because considerations of comity are also present in Eleventh Amendment doctrine.

338. Id.

339. Id.

340. A defense merely allows a defendant to escape liability, while immunities are designed to spare litigants the cost and trouble of appearing in court. Immunities themselves come in many different varieties. For a discussion of various official immunities, see CHEMERINSKY, supra note 23, at 493-523; see also In re Stock Exch. Options Trading Antitrust Litig., 317 F.3d 134, 151 (2d Cir. 2003) (reviewing differences between immunities and jurisdiction and discussing differences among various types of immunities).

341. 506 U.S. 139, 141, 143 (1993).

342. 217 F.3d 951, 953-54 (7th Cir. 2000). 
Thus a conceptualization of sovereign immunity as a defense, the court reasoned, could be reconciled with existing doctrine stating that courts can raise sovereign immunity defenses sua sponte and that states may introduce them on appeal. The court observed:

[Considering] the immunity conferred by the Eleventh Amendment [to be] no different from any other affirmative defense [would not] comport with the long line of cases holding that federal courts may forgive the waiver of a defense that is based on comity-the mutually respectful deportment of sovereign entities, including the quasi-sovereign entities that are the states of the United States. ${ }^{343}$

As Puerto Rico Aqueduct and Higgins explain, defenses and immunities take many forms and can be subject to comity considerations or other incidents of the relationships between sovereigns. A defense/immunity model is thus inherently more able to accommodate the distinctive facets of sovereign immunity doctrine than a jurisdictional view.

A final argument for the defense/immunity view is that it would comport with one important aspect of lower court practice and understanding. In general, lower courts treat sovereign immunity procedurally as an affirmative defense. In most courts, for example, a state asserting a sovereign immunity defense bears the burden of proving the relevant facts. ${ }^{344}$ As some courts have recognized, this practice is inconsistent with the jurisdictional view. ${ }^{345}$ Yet assigning the burden to the state makes good sense in many respects. In ITSI TV Productions, Inc. v. Agricultural Ass'ns, ${ }^{346}$ the Ninth Circuit noted that a sovereign immunity claim "will occasion serious dispute only where a relatively complex institutional arrangement makes it unclear whether a given entity ought to be treated as an arm of the state"; in such a case, the state has far better access to the underlying facts. ${ }^{347}$ As the Ninth Circuit recognized, placing the burden of proof on the state is thus fairer and more efficient. Assignment of the burden of proof can also be viewed as a necessary counterweight to the state's ability to assert sovereign immunity claims late in litigation, a power that would otherwise be far more subject to abuse for strategic purposes. Perhaps courts could find a way to reconcile the assignment of the burden of proof with a holding that sovereign immunity is jurisdictional, but it would add yet another anomaly to an already conundrum-riddled doctrine. For the Supreme Court

\footnotetext{
343. Id. at 954.

344. See supra note 234.

345. See Union Pac. R.R. Co. v. Burton, 949 F. Supp. 1546, 1550 (D. Wy. 1996) (noting procedural problems posed by treating state sovereign immunity as a defense).

346. 3 F.3d 1289 (9th Cir. 1993).

347. Id. at 1292.
} 
to endorse the immunity/defense view would provide a considerably easier way out. ${ }^{348}$

\section{V. \\ CONCLUSION}

Subject matter jurisdiction is not a matter of choice or a weighing of costs and benefits; it is a constitutional limitation on federal judicial power that can be changed only by amendment. To some extent, it must be applied rigidly and formalistically. When an Article III issue appears in a case, federal courts must take it seriously and sometimes treat it in ways that might seem harsh or irrational were no jurisdictional issue involved. As a result, it is to everyone's advantage - courts, litigants, and anyone who participates in a federalist system of government - to have the bounds of subject matter jurisdiction clearly articulated and grounded in constitutional principles.

While some legal doctrines may be able to tolerate a degree of uncertainty, the jurisdictional status of sovereign immunity is not one of them. Precisely because the doctrine has never been anchored clearly in constitutional text, the Supreme Court's expositions of sovereign immunity have taken on particular significance in anchoring the doctrine and establishing its contours. Insofar as the Court now considers the doctrine a fundamental constitutional principle - even if it is better conceived as a constitutionally rooted immunity or a limitation on federal power than as an Article III restriction per se - it is particularly important for lower courts to understand its boundaries.

The Court could take a large step toward clarifying current doctrine by squarely holding that sovereign immunity is not a question of subject matter jurisdiction, and, preferably, by characterizing it instead as a defense or immunity. While substantial questions about the scope of sovereign immunity's application would remain, lower courts would no longer have to approach those issues through the distracting and inappropriate

348. It is worth noting that an additional justification exists for all three nonjurisdictional views (rights, personal jurisdiction, and defense/immunity), which hinges on an important difference in the parties' incentives for enforcing state sovereign immunity restrictions as opposed to jurisdictional ones. Where subject matter jurisdiction is concerned, the structural values Article III is designed to protect may not coincide with the parties' self-interest in the litigation. The parties, therefore, cannot always be trusted to raise jurisdictional issues on their own, and special procedural mechanisms (such as the requirement that courts establish their jurisdiction before hearing the merits of the case) may be necessary to ensure that the court does not overstep the limits of its constitutional powers. Where state sovereign immunity is at issue, however, one of the parties is by definition a state. Because states are sophisticated actors and repeat participants in litigation, there is no reason to think that they cannot adequately vindicate all the constitutional protections that state sovereign immunity is designed to secure to them. In other words, the state's incentives in any given case are sufficient to ensure protection of the larger structural interests that state sovereign immunity serves. I am grateful to Stephen McG. Bundy for this insight. 
framework of Article III. Past cases make clear that the Supreme Court has described sovereign immunity in nonjurisdictional terms far more frequently than jurisdictional, and has understood and applied sovereign immunity in ways inconsistent with viewing it as a limit on subject matter jurisdiction. The jurisdictional view, in short, is one that the Supreme Court has never explicitly defended or consistently adhered to. It is time for the Court to make its doctrine consistent with its language and practice. 
